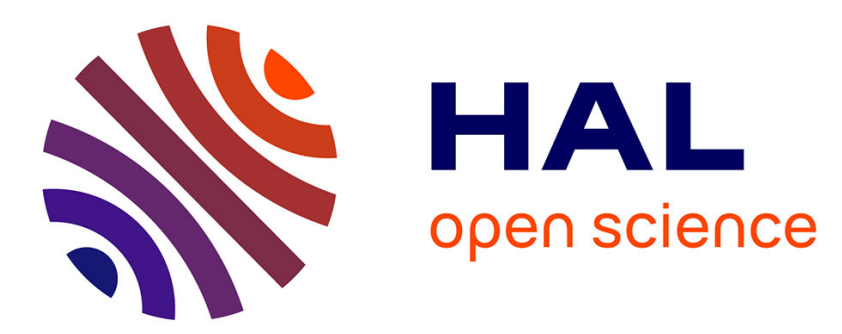

\title{
Cenozoic tectono-geomorphological growth of the SW Chinese Tian Shan: insight from AFT and detrital zircon $\mathrm{U}-\mathrm{Pb}$ data
}

Yingying Jia, Bihong Fu, Marc Jolivet, Shuo Zheng

\section{- To cite this version:}

Yingying Jia, Bihong Fu, Marc Jolivet, Shuo Zheng. Cenozoic tectono-geomorphological growth of the SW Chinese Tian Shan: insight from AFT and detrital zircon U-Pb data. Journal of Asian Earth Sciences, 2015, 111, pp.395-413. 10.1016/j.jseaes.2015.06.023 . insu-01168519

\section{HAL Id: insu-01168519 \\ https://hal-insu.archives-ouvertes.fr/insu-01168519}

Submitted on 26 Jun 2015

HAL is a multi-disciplinary open access archive for the deposit and dissemination of scientific research documents, whether they are published or not. The documents may come from teaching and research institutions in France or abroad, or from public or private research centers.
L'archive ouverte pluridisciplinaire HAL, est destinée au dépôt et à la diffusion de documents scientifiques de niveau recherche, publiés ou non, émanant des établissements d'enseignement et de recherche français ou étrangers, des laboratoires publics ou privés. 


\section{Cenozoic tectono-geomorphological growth of the SW Chinese}

\section{Tian Shan: insight from AFT and detrital zircon U-Pb data}

Yingying Jia ${ }^{1,3}$, Bihong $\mathrm{Fu}^{2,3^{*}}$, Marc Jolivet ${ }^{4}$, Shuo Zheng ${ }^{5}$

${ }^{1}$ Institute of Geology and Geophysics, Chinese Academy of Sciences, Beijing 100086,

China

${ }^{2}$ Kashgar Research Centre, Institute of Remote Sensing and Digital Earth, Chinese

Academy of Sciences, Beijing 100094, China

${ }^{3}$ University of Chinese Academy of Sciences, No.19A Yuquan Road, Beijing 100049,

China

${ }^{4}$ Laboratoire Géosciences Rennes, Université Rennes 1, UMR 6118 CNRS/INSU,

Rennes, France

${ }^{5}$ Key Laboratory of Environment Change and Natural Disaster of MOE, Beijing

Normal University, Beijing 100875, China

Corresponding author: Dr. Bihong Fu

Address: Institute of Remote Sensing and Digital Earth, Chinese Academy of

Sciences.

No.9 Dengzhuang South Road, Haidian District, Beijing 100094, China

Tel: +86-10-82178096 
E-mail: fubh@radi.ac.cn

\section{Abstract}

As a unique example of the intracontinental mountain building, the Cenozoic deformation of the Tian Shan has been widely studied. The onset of Cenozoic exhumation of the SW Chinese Tian Shan was constrained at the Oligocene-Miocene boundary. However, the Cenozoic tectono-geomorphological growth process of the SW Chinese Tian Shan and adjacent piedmont basins remains a challenge. In this study, we carried out the geological mapping of satellite images and field investigations together with the apatite fission track (AFT) and detrital zircon $\mathrm{U}-\mathrm{Pb}$ analyses to get further understanding of the Cenozoic tectonic deformation and geomorphological growth of the SW Chinese Tian Shan. Our results indicate that the exhumation of Maidan fault or topography growing of the Kokshaal Range commenced in the late Eocene Oligocene $(35$ - $25 \mathrm{Ma})$. Then, the structural deformation migrated southward to the Muziduke fault and the Atushi Basin Thrust (ABT) at $\sim 15$ Ma. The growth strata of $6-3$ Ma on the south flank of Keketamu Anticline imply that tectonic deformation propagates further basinward. Furthermore, the uplift of the Kokshaal Range also strongly affected the evolution of piedmont basins. The results suggest that the Atushi Basin was still likely linked to the Aksai Basin during the early Miocene. They were separated into two independent basins since ca. 13.7 - 10.5 Ma, as a response to the rapid uplift of the Kokshaal Range. Finally, we infer that the southeastern part of dextral Talas-Fergana fault (TFF) is 
likely transferred to the NEE-trending thrust faults of the SW Chinese Tian Shan since $\sim 15$ Ma.

Key words: Tectono-geomorphological evolution; Cenozoic; Apatite fission track; Atushi Basin; Tian Shan 


\section{Introduction}

The Tian Shan is a $2500 \mathrm{~km}$ long orogenic belt in central Asia with the highest peaks up to 7400m (Molnar and Tapponnier, 1975; Allen et al., 1993). The currently active Tian Shan is flanked by east-west trending active thrusts on both north and south piedmonts (Molnar and Tapponnier, 1975; Avouac et al., 1993). Presently, the compressive to transpressive deformation is distributed across the whole width of the range as indicated by the widespread seismicity (Avouac and Peltzer, 1993; Abdrakhmatov et al, 1996; Fu et al., 2003, 2010; Burtman, 2012).

Forming the southern edge of the Central Asian Orogenic Belt (CAOB), the ancient Tian Shan Orogen recorded a complex history of amalgamation of a number of continental and oceanic terranes during the Palaeozoic (e.g., Allen et al., 1993). The resulting late Carboniferous - early Permian orogen was then repeatedly reactivated during the Mesozoic and the early Cenozoic in response to distant collisions of island arcs and continental blocks with the southern margin of Asia (Molnar and Tapponnier, 1975; Hendrix et al., 1994; Dumitru et al., 2001; Jolivet et al., 2010, 2015; Maculay et al., 2014). Finally, during the late Cenozoic, the Tian Shan has been characterized by a renewed and intense episode of tectonic reactivation due to the ongoing India-Eurasia convergence. This reactivation is responsible for the formation of the modern Tian Shan topography (Hendrix et al., 1994; Yin et al., 1998; Sobel et al., 1997, 2006a; Zhang et al., 2009; De Grave et al., 2013; Maculay et al., 2014; Bande et al., 2014, 2015). Low-temperature thermochronological data indicate that the timing 
of uplift varies from east to west and north to south within the range and the pre-existing basement architectures played a significant role in the intracontinental deformation. It initiated throughout the whole range through the reactivation of pre-existing basement structures, and the deformation gradually propagated towards both the south and north piedmonts (Dumitru et al., 2001; De Grave et al., 2007; Jolivet et al., 2010; Glorie et al., 2011; Macaulay et al., 2014).

The SW Chinese Tian Shan, located in the southeastern side of the Talas-Fergana fault (TFF) and adjacent to the Pamir to the south (Fig. 1 and 2a), is an excellent area to study the Cenozoic deformation and landscape evolution of the Tian Shan caused by the India-Asia collision. Apatite Fission Track (AFT) data indicate the exhumation of this region commenced at $\sim 24$ Ma (Sobel et al., 2006a). By comparing with geodetic data, Sobel et al. (2006a) suggested this region experienced a complex shortening history in late Cenozoic. Four stages of tectonic deformation in the Atushi Basin in front of the SW Chinese Tian Shan at $20 \sim 25 \mathrm{Ma}$, ca.16.3 Ma, $4 \sim 13.5 \mathrm{Ma}$ and after $4 \mathrm{Ma}$ were constrained by magnetostratigraphic study, which lead to a total north south shortening of $10-32 \mathrm{~km}$ (Heermance et al., 2008). The kinematic mechanism of the Atushi and Kashi folds were well constrained by Scharer et al. (2004) and Chen et al. (2007).

However, the Tian Shan Range experienced a thermal stable episode in late Jurassic and Cretaceous (e.g., Dumitru et al., 2001; Jolivet et al., 2010) and large areas of low-relief surface with late Jurassic AFT ages preserved throughout the range 
(Cobbold et al., 1996; Burbank et al., 1999; Oskin and Burbank, 2007; Macaulay et al., 2013). Previous detrital zircon study also indicates a Mesozoic - early Cenozoic flat topography in the Wuqia region, $30 \mathrm{~km}$ west to the study area (Yang et al., 2013). The low relief surface on the north flank of the Kokshaal Range is spatially correlated to the regional Mesozoic relict surface (Fig 2b). If the low-relief surface of the study area is corresponding to the Atushi Basin floor, it likely indicates at least $2200 \mathrm{~m}$ uplift of the range and $1700 \mathrm{~m}$ of the Aksai Basin in Cenozoic (Fig. 2b). Although the Cenozoic tectonic evolution of the SW Chinese Tian Shan is well constrained by previous studies, it is unclear whether the Aksai Basin and the Atushi Basin were connected with each other and then separated by the growing Kokshaal Range. The regional landscape evolution of the study area driven by the Cenozoic tectonic deformation still needs more research.

In this study, we carried out the geological interpretation of satellite imagery and field mapping combined with the apatite fission track and detrital zircon $\mathrm{U}-\mathrm{Pb}$ analyses in order to further understand the tectono-geomorphological growth process in the SW Chinese Tian Shan and adjacent piedmonts basin during the Cenozoic.

\section{Geological setting}

The Kokshaal Range is located south to the Aksai Basin and the Atbashi Range, and north to the Atushi Basin (Fig. 2 a). The Atbashi Range is considered as a part of the South Tian Shan suture (STSs). This portion of the Tian Shan represents a late Palaeozoic collision-accretion system and is characterized by complex fold-and-thrust 
structures (Konopelko et al., 2007, 2009). Most of the rocks in the Kokshaal Range are Carboniferous-Devonian quartz-rich sandstones and limestone (BGMRXJ, 1993). The Cretaceous strata exposed in the Atushi Basin are characterized by red sandstones. The Atushi Basin contains $>6 \mathrm{~km}$ thick Cenozoic sedimentary sequences that unconformably overlaying on the Cretaceous and Palaeozoic strata (Chen et al., 2007; Heermance et al., 2007). These Cenozoic sedimentary rocks are composed of the Wuqia Group $\left(\mathrm{N}_{1}\right.$ wq), Atushi Fm. $\left(\mathrm{N}_{2} \mathrm{a}\right)$ and Xiyu Fm. $\left(\mathrm{Q}_{1} \mathrm{X}\right)$ (Chen, et al., 2002; Heermance, et al., 2007; Fig. 3b and 4), that are conformably contacted with each other. The Wuqia Group was divided into Keziluoyi Fm., Anjuan Fm. and Pakabulake Fm. from the bottom to the top by BGMRXJ (1993). The Keziluoyi Fm. is composed by pale yellow-red poorly consolidated siltstone, sandstone, and conglomerate riched in well rounded chert pebbles. And, the Anjuan Fm. is composed by interbedded greyish green siltstone, sandstone with gypsum. The Pakabulake Fm. consists of dark brown and grey siltstone and shale interbedded by sandstone. The age of the Keziluoyi and Anjuan Fms. were constrained between $17.5 \sim 13.7$ Ma by magnetostratigraphy analysis, and the depositional age of the Pakabulake Fm. is 13.7

- 5.3 Ma (Heermance et al., 2007). The Pliocene Atushi Fm. consists of yellow brown-tan sandstone, siltstone, mudstone, gypsum and rare conglomerate with a bottom depositional age of $\sim 5.3 \mathrm{Ma}$. The Xiyu Fm. is composed by thick grey calcite-cemented conglomerate. Previous studies suggest that the Xiyu Fm. is a time-transgressive lithofacies (Chen et al., 2002; Heermance et al., 2007). Heermance 
et al. (2007) stated that the deposition of the Xiyu Fm. initiated at 15.5 Ma in the middle of the Atushi Basin. However, the mid-Miocene conglomerate interpreted as debris flow deposits is remarkably different from the Xiyu Fm.

In this region, the western Tarim block is underthrust beneath the Tian Shan range on the east side of the TFF at a rate of $\sim 8-10 \mathrm{~mm} / \mathrm{yr}$ (Abdrakhmatov et al., 1996; Mohadjer et al., 2010; Zubovich et al., 2010) and leads to the compressive deformation at the south side of Tian Shan and its piedmont basins (Fig. 2a). Topographically, the elevation gradually reduces from over $4200 \mathrm{~m}$ in the range to $1500-2300 \mathrm{~m}$ in the Atushi Basin (Fig. 2b). The Aksai intra-mountain basin north to Kokshaal Range is up to $3200 \mathrm{~m}$ high (Fig. 2b). The large-scale topography of the study area is generated by a major south-vergent reverse faults system including the main Maidan and Muziduke faults (Figs. 2a, 3b and 4). These faults are inherited late Palaeozoic thrust system (Allen et al., 1999; Chen et al., 2001), and the Cenozoic activation commenced at the Oligocene-Miocene boundary (Sobel et al., 2006a). Towards to the south, the thrusting of the Atushi Basin Thrust (ABT), which juxtaposes the Palaeozoic strata with the Cenozoic strata in the middle of the Atushi Basin (Figs. 2a and 4a), initiated at 15 Ma (Heermance et al., 2008). Immediately south of the ABT, the geological structures consist of a series of fault-related folds: the Tashipisake, the Keketamu, the Atushi and the Kashi anticlines from north to south (Figs. 2a, 3b and 4a; Fu et al., 2010), which were deformed at 13.5 Ma, $4 \mathrm{Ma}$, 1.4 - 1.2 Ma and 1.4 - 1.07 Ma, respectively (Chen et al., 2007; Heermance et al., 
2008). The total amount of late Cenozoic shortening across the fold system is up to 9.3km, and the deformation is still ongoing (Scharer et al., 2004; Fu et al., 2010).

The northwest extending Talas-Fergana fault over $2000 \mathrm{~km}$-long is another spectacular structural feature in the study area. It represents one of the largest intracontinental strike-slip faults, and experienced a complex strike-slip movement from Palaeozoic to Quaternary with a maximum dextral displacement of $200 \mathrm{~km}$ and Cenozoic offset of $60 \pm 10 \mathrm{~km}$ (Burtman et al., 1996). While Burtman et al. (1996) stated that the Cenozoic dextral strike slip faulting occurred in $4-12.5 \mathrm{Ma}$ with an average rate of $10 \pm 2 \mathrm{~mm} / \mathrm{yr}$, Bande et al. $(2014,2015)$ proposed that the strike-slip motion along the TFF commenced at ca. $25 \mathrm{Ma}$ based on low-temperature thermochronologic study of the transpressional pop-up structures of this fault. Although the timing of the Cenozoic deformation of this large fault is still debatable, the tectonic evolution of the SW Chinese Tian Shan is strongly affected by the TFF.

Numerous low-temperature thermochronology data, including AFT, AHe, ZHe, have already roughly constrained the Mesozoic to Cenozoic uplift history of the Western Tian Shan (Fig. 5; Bullen et al, 2001; Sobel et al., 2006a, 2006b; De Grave et al., 2007, 2011, 2012, 2013; Glorie et al., 2010, 2011; Zhang et al., 2009; Chang et al., 2012; Macaulay et al., 2014). While the Mesozoic cooling AFT and AHe ages are widespread across the whole Tian Shan Range (Fig. 5), recording the accretion of the various Cimmerian blocks to the southern Eurasian margin (Roger et al., 2008, 2010; Jolivet, 2010, 2015), the early Cenozoic uplift history is more heterogeneous across 
the range. AFT ages of 40 - 60 Ma obtained along the Atbashi Range might represent the incipient reactivation of STSs (Glorie et al., 2011). They are consistent with early Paleogene ( 60 - 40Ma) AFT ages from detrital samples in the Aksai Basin (Glorie et al., 2011) as well as with early Paleogene basement AFT ages obtained along the Narat fault over $850 \mathrm{~km}$ east to the study area (Jolivet et al., 2010). Oligocene-Miocene cooling ages corresponding to the onset of main deformation phase, which formed the modern Tian Shan, were detected along most of the sub-ranges except the southern flank of the Kyrgyz Range (Sobel et al., 2006a, 2006b; De Grave et al., 2007, 2010, 2012, 2013; Zhang et al., 2009; Glorie et al., 2010, 2011; Chang et al., 2012; Macaulay et al., 2013, 2014; Bande et al., 2014, 2015). AFT thermal modelling revealed a late Cenozoic reheating event along the Kyrgyz Range, Atbashi Range and Kokshaal Range, which might reflect sediment loading in this region or local tectonic burying in these regions (Sobel et al, 2006a, 2006b; Glorie et al, 2011). An intensive exhumation event occurred during the late Miocene to Pliocene (10 - $3 \mathrm{Ma})$ was found along the Atbashi Range, the northern flank of Kyrgyz Range and the central Kyrgyz Tian Shan (Bullen et al., 2001; Sobel et al, 2006b; Glorie et al, 2011; Macaulay et al., 2014).

\section{Method}

\subsection{Geological and geomorphological mapping of remote sensing data}

Geological and geomorphological mapping were carried out using the remote sensing data such as the SRTM DEM data with resolution of $90 \mathrm{~m}$, Landsat TM data with 
resolution of $30 \mathrm{~m}$, ASTER data with resolution of $15-30 \mathrm{~m}$, together with field observations. The Cenozoic lithological units and structural deformation in the SW Chinese Tian Shan and piedmont basins can be distinguished from these enhanced images.

\subsection{AFT}

The apatite fission-track (AFT) method is a low-temperature thermochronological technique based on the spontaneous fission decay of ${ }^{238} \mathrm{U}$, that enables to reconstruct the thermal history of the host rocks between $\sim 60-120^{\circ} \mathrm{C}$ (Donelick, et al., 2005). Four samples from Carboniferous sedimentary rocks forming the basement of Kokshaal Range, as well as eight detrital samples from Cretaceous and Cenozoic strata of the Atushi Basin were collected along a north-south extending profile. The locations of samples are marked on Fig. $3 \mathrm{~b}$ and Fig. 5a, and their lithological characteristics and GPS information are also listed in Table 1.

A detailed description of methodology can be found in Jolivet et al., 2010. The apatite crystals were mounted on glass slides using epoxy glue and polished. Samples were etched in $6.5 \% \mathrm{HNO}_{3}$ for $45 \mathrm{~s}$ at $20^{\circ} \mathrm{C}$ to reveal the spontaneous fission tracks (Seward et al., 2000; Jolivet et al., 2001), before being irradiated with a neutron fluence rate of $1.10^{16}$ neutrons $/ \mathrm{cm}^{2}$ at the Oregon State University Reactor (USA). The micas used as external detector were etched in $40 \% \mathrm{HF}$ for $40 \mathrm{~min}$ at $20{ }^{\circ} \mathrm{C}$ in order to reveal the induced fission tracks. The ages were calculated following the method recommended by the Fission Track Working Group of the International Union of 
Geological Sciences Subcommission on Geochronology (Hurford, 1990) using the zeta calibration method (Hurford and Green, 1983). CN5 glass was used as a dosimeter. Ages were calculated using an overall weighted mean zeta value of $342.7 \pm$ $4.5 \mathrm{yr} \mathrm{cm}^{2}$ (J. Y.), obtained on both Durango (McDowell et al, 2005) and Mount Dromedary apatite standards (Green, 1985; Tagami, 1987). Fission tracks were counted on a ZeissM1 microscope, using a magnification of 1250 under dry objectives and the Autoscan ${ }^{\circledR}$ software (on manual mode). Data are reported in Table 2.

Within basement samples, the lengths of horizontal confined fission tracks were measured on sections parallel to the c-axis in order to perform thermal history modelling. The modelling was carried out using the QTQt software (Gallagher et al., 2009, 2012) with the multi-kinetic annealing model of Ketcham et al, 2007. Dpars (Donelick, 1993; Barbarand, 2003) of every single grain that were dated and the most grains that were used for length measurement, the arithmetic mean fission-track etch figure diameter parallel to the crystallographic c-axis, were also measured to better constrain the thermal history modelling and the statistical analysis of single grains ages of detrital samples. The measured Dpar values were roughly corrected following the method of Sobel and Seward (2010). The correction factor is 1.19 and the corrected Dpars were reported in Table. 2.

The fission track pooled ages are reported for samples that pass the $\chi^{2}\left(\mathrm{P}\left(\chi^{2}\right)>5 \%\right)$ test and central ages are reported for detrital samples with $\mathrm{P}\left(\chi^{2}\right)<5 \%$ (Table. 2 ). 
The AFT ages from an unreseted detrital sample reflect a mixture of component populations eroded from different source regions. Decomposing of AFT ages of detrital samples in this study was carried out using Bayersmix software (Jasra et al., 2005). This method is based on mixture models with flexibility in the class of component densities using Markov chain Monte Carlo (MCMC) method (Gallagher et al., 2009). In this case, the number of age components with the highest probability will be given by the calculation. Finally, a credible result can be obtained based on the number with highest probability (Jasra et al., 2005; Gallagher et al., 2009) (Table. 3 and Fig. 8).

\subsection{Detrital zircon}

Detrital zircon U-Pb dating was carried out for the 6 samples from Cenozoic sediment in the Atushi Basin. More than 1000 detrital zircons per sample were separated by standard heavy liquid, magnetic techniques and randomly selected, of which more 300 grain were mounted in epoxy resin and polished for LA-ICP-MS (laser ablation-inductively coupled plasma-mass spectrometer) U-Pb dating. Cathodoluminescence (CL) images were obtained to reveal internal structures of zircons using a LEO1450VP Scanning Electron Microscope. U-Pb analysis was conducted on an Agilent 7500a Q-ICP-MC connected to a 193nm laser ablation system of MC-ICPMS (Neptune) in IGGCAS. The ablation spot size was between 60 and $44 \mathrm{~nm}$. Helium was used as the carrier gas to enhance the transport efficiency of the ablated material (Gao et al., 2008). Zircon grains without visible fractures and 
inclusions were selected randomly in each sample mount. The zircon standard 91500 was used as external standard for the age calculation and NIST SRM 610 as external standard for the concentration calculation in conjunction with the internal standardization using ${ }^{29} \mathrm{Si}\left(32.8 \% \mathrm{SiO}_{2}\right.$ in zircon). After isotopic ratios and elemental concentrations calculation using GLITTER 4.0, Isoplot 3.15 was used for plotting of Concordia diagrams and analysis of detrital zircon age distribution. The ${ }^{207} \mathrm{~Pb} /{ }^{206} \mathrm{~Pb}$ age is used when the age is $>1000 \mathrm{Ma}$ and the ${ }^{206} \mathrm{~Pb} /{ }^{238} \mathrm{U}$ is used when the age is < $1000 \mathrm{Ma}$, which can provide more reliable age estimation for these younger grains due to the low content of radioactive $\mathrm{Pb}$ and the uncertainties in common lead correction (Sircombe, 1999; Li et al., 2010). Zircon grain ages with discordance degree $>10 \%$ were excluded for our analysis.

\section{Result}

\subsection{Geomorphological analysis}

Different lithological units can be distinguished according to their spectral and texture characteristics of satellite images. The ASTER pseudo color image (R: band ratio 2/1, G: band 3 and B: band ratio 4/8) (Fig. 3a) was produced and a detail geological mapping (Fig. 3b) was made based on interpretation of satellite image and field observations. The Kokshaal range is bounded by the TFF on the western side and by thrusts and folds on the southern side, where the relief is much higher and the stream networks are well developed and deeply incised into the bedrock (Fig. 2a). By contrast, a large area of low-relief surface with a mean elevation of $3500-4000 \mathrm{~m}$ is 
well preserved on the northern flank of the range, slightly tilted by the Maidan and the Muziduke faults (Fig. 2a). These low-relief surface can be traced throughout the whole Tian Shan Range (e.g., Cobbold et al., 1996; Burbank et al., 1999; Oskin and Burbank, 2007; Macaulay et al., 2013), and are usually characterized by late Palaeozoic-Mesozoic AFT and ZHe ages (e.g., Jolivet et al., 2010; Glorie et al., 2011; Zhang et al., 2011), indicating the finite erosion since Mesozoic. Jolivet et al. (2010) suggested that these surfaces were formed during the late Jurassic-Cretaceous tectonic quiescence period. The low-relief surfaces are stratigraphically correlated with the regional unconformity surface between the Palaeozoic and Mesozoic-early Cenozoic sedimentary sequences (Vakhrameev, 1964; Zhukov, 1969; Turchinskiy, 1970; Pomazkov, 1972; Cobbold et al., 1996). And, the unconformity can be considered to be a nearly horizontal datum before the Cenozoic and provides key controls on the magnitude of the Cenozoic deformation of the Tian Shan (Burbank et al., 1999). Therefore, the low-relief surfaces in the Kokshaal Range are stratigraphically correlated with the thin Cretaceous sedimentary rocks in the Atushi Basin, and the total surface uplift of over $1700 \mathrm{~m}$ in the Kokshaal Range occurred relatively to the Atushi Basin in the Cenozoic. In addition, patches of that low-relief surface with similar elevation are locally preserved on the footwall of the Maidan fault east to the Boguzi River (Fig. 2a), implying that the thrusting of this fault is faint to the east. Extremely asymmetrical (Fig. 2a) catchment basins are well developed along the Maidan fault and another small fault to the north, likely indicating a dextral strike-slip 
movement along these faults. The Muziduke fault is poorly exposed because of the extensive Quaternary sediments.

Growth strata initiated at 4.7 Ma (Heermance et al., 2007) were observed on the south flank of the Keketamu anticline by our field investigation. The dip angle gradually decreases from nearly vertical at the bottom of the Xiyu Fm. to $38^{\circ}$ near the top (Fig. 4b). As the dip angle of the strata changes, the clast compositions are heterogeneous as well. While limestone pebbles are the dominant clast type in the lower part of Xiyu Fm., the middle part of the Xiyu conglomerate is mainly composed by yellow and red sandstone pebbles (Fig. 4b). Then, the component of limestone pebbles increases at the top of the Xiyu Fm. (Fig. 4b). The pebble counting is similar with the method used by the Heermance et al (2007).

\subsection{AFT Results}

\subsubsection{Basement samples}

Four Carboniferous basement samples were collected from the hanging wall of the Muziduke fault along the Hejiante River (Fig. 3b and 4). Sample TK-09 located less than 100 meters south of the Maidan fault has a pooled age of $81.3 \pm 4.7 \mathrm{Ma}$. Confined track lengths measurements of this sample yield a mean length of $10.2 \pm 2.3$ $\mu \mathrm{m}$ and are characterized by a wide unimodal length frequency distribution (Fig. 6). The track lengths are comprised between 5 and $15 \mu \mathrm{m}$, indicating a slow cooling across the partial annealing zone (PAZ). A few long tracks $(>15 \mu \mathrm{m})$ possibly indicate a rapid exhumation after a first period of slow cooling. The mean $\operatorname{Dpar}_{C}$ value is 1.51 
$\mu \mathrm{m}$ with a small standard deviation $(\sigma=0.14 \mu \mathrm{m})$. Sample TK-10 located $2.1 \mathrm{~km}$ south of the Maidan fault has a pooled age of $193.4 \pm 8.2$ Ma with a mean confined track length of $10.8 \pm 1.7 \mu \mathrm{m}$ and a $\operatorname{Dpar}_{C}$ value of $1.52 \pm 0.18 \mu \mathrm{m}$. While some short tracks are preserved, most of the track lengths range between 7 and $14 \mu \mathrm{m}$ (Fig. 7). The distribution of the confined track length indicates a slow cooling across the PAZ. Samples TK-12 and TK-13 have pooled ages of $28.8 \pm 2.5 \mathrm{Ma}$ and $25.7 \pm 3.0 \mathrm{Ma}$, respectively. They are situated $4.5-5 \mathrm{~km}$ south of the Maidan fault. Few confined tracks could be observed and measured in both samples not allowing any data modelling. The thermal history model of the TK-09 and TK-10 are similar. Both samples exhibit two phases of exhumation. As the Mesozoic AFT ages are widespread across the whole Tian Shan Range, an early Cretaceous (130 -145 Ma) cooling event can also be observed from the thermal history of TK-09 and TK-10 (Fig. 6). Following that initial exhumation, the sample experienced a $25-70{ }^{\circ} \mathrm{C}$ reheating from Oligocene to early Miocene (35 - $25 \mathrm{Ma}$ ) before the Miocene rapid exhumation. This reheating phase was likely caused by burial beneath either Cenozoic sediment loading or the southward propagating hanging wall of the Maidan fault. Similar reheating event observed in samples TK-09 and TK-10 was also reported from AFT thermal modelling of the sample 99WT-3, $7 \mathrm{~km}$ south of the Maidan fault (Sobel et al., 2006a), and in the Kyrgyz Range to the north and in the Aksu to the east (Glorie et al., 2011; Sobel et al., 2006b; Zhang et al., 2009). Finally, both models thus show an intense exhumation phase during the late Cenozoic (ca. $15 \mathrm{Ma}$ ). 


\subsubsection{Detrital samples}

Eight detrital samples were collected from the late Cretaceous Kezilesu Group to the Xiyu Fm. in the Atushi Basin (Fig. 3band 4a). All detrital samples fail the $\chi^{2}$ test and they show widely spread single-grain ages, spanning largely above the stratigraphical age and indicating that none of those detrital samples have been totally reseted.

In order to check for the occurrence of some chemical control or crystal structures on fission track annealing rates, we measured Dpar values for every single grain in each detrital sample. The Dpar parameter corresponds to the diameter of the etched trace of the intersection of a fission track with the surface of the studied crystal measured parallel to the c axis. Apatite fission track annealing rates and closure temperatures are largely sensitive to the etching characteristics (Dpar) (Carlson, et al., 1999; Barbarand et al., 2003; Donelick, et al., 2005; Woelfer et al., 2008). For example, apatite grains with relatively high Dpar value usually anneal more slowly than their low Dpar counterparts (Carlson, et al., 1999; Donelick, et al., 2005). Then, as the AFT ages of apatite grains with low Dpar values decrease more rapidly than that of apatite grains with high Dpar values. If samples are intensively reheated, apatite grains with small Dpar values might reach their close temperature and show young ages, others with large Dpar values may still stay in their PAZ and exhibiting older single grain ages. In this case, the Dpar value and single grain ages might show a faint positive relationship. Altogether, the $\operatorname{Dpar}_{C}$ values within our detrital samples vary between 1.27 and $7.28 \mu \mathrm{m}$. No obvious correlation or inconspicuous negative correlation 
between the single grain ages and the Dpar values can be observed for each detrital sample (Fig. 7), indicating that no detrital samples were reseted.

Sample SWTS-04 from the late Cretaceous Kezilesu Group has a mean AFT age of $220.7 \pm 10.0 \mathrm{Ma}$ (Fig. 8), which is much older than the depositional age of the strata, and apparently shows the provenance signal. The single grain ages of this sample spread from $102 \pm 33$ Ma to $382 \pm 185$ Ma (Fig.9). Sample WY-03 was collected from the red conglomerate immediately in front of the Atushi Basin Thrust (ABT), for which a depositional age of 15.5 Ma has been obtained (Heermance et al., 2007). The conglomerate can only be traced locally along that particular thrust. It contains angular sandstone pebbles and large Palaeozoic limestone megaclasts, considered as debris flow deposit (Heermance et al., 2007). The AFT single-grain ages exhibit a widespread range between $375 \pm 139 \mathrm{Ma}$ and $20 \pm 10 \mathrm{Ma}$. $\operatorname{Dpar}_{C}$ values range between $1.49 \mu \mathrm{m}$ to $5.34 \mu \mathrm{m}$, with a large standard deviation $(\sigma=0.92 \mu \mathrm{m})$ and no obvious correlation can be detected between AFT ages and $\operatorname{Dar}_{C}$ values of single grains. The youngest age component is $34.5 \pm 5.9 \mathrm{Ma}$ (Fig. 8 and Table. 3). An early Cretaceous $(118.6 \pm 7.1 \mathrm{Ma})$ and a late Triassic $(219.9 \pm 7.4 \mathrm{Ma})$ age components were observed as well. SWTS-01 and SWTS-02 were collected from the top of the red conglomerate. Only 22 grains were obtained from sample SWTS-02. The sample shows wide AFT age distribution ranging from $17 \pm 5 \mathrm{Ma}$ to $363 \pm 70 \mathrm{Ma}$, and the absence of correlation between AFT ages and $\operatorname{Dpar}_{C}$ values $(2.49-5.15 \mu \mathrm{m})$ indicates that the sample was not reseted after deposition. While the youngest age component is 
$28.6 \pm 9.1 \mathrm{Ma}$, the sample also contains a late Cretaceous age component of $83.1 \pm$ 10.2 Ma and an early Jurassic age component of 184.4 $\pm 11.0 \mathrm{Ma}$ (Fig. 8 and Table. 3). Fifty apatite grains were obtained from sample SWTS-01. The sample again shows a widespread range of AFT ages between $15 \pm 11$ Ma and $505 \pm 295$ Ma with Dpar $_{C}$ values from 1.27 to $4.20 \mu \mathrm{m}$ with a large standard deviation $(\sigma=0.52)$. Three age components of $32.1 \pm 10.8 \mathrm{Ma}, 108.2 \pm 14.6 \mathrm{Ma}$ and $226.3 \pm 13.7 \mathrm{Ma}$ are observed (Fig. 8 and Table. 3), relatively similar to those of sample SWTS-02. Sample KKTM-08 was collected from the bottom of the Pakabulake Fm. with a depositional age of 13.7 Ma (Heermance et al., 2007). As in all the other detrital samples, a wide range of AFT ages (between $7 \pm 4$ and $283 \pm 140 \mathrm{Ma}$ ) was obtained and no positive correlation could be observed between the single grain AFT ages and the $\operatorname{Dpar}_{C}$ values in this sample. Dparc values are widely spread between 1.79 and $4.76 \mu \mathrm{m}$. Two age components are observed, a Miocene age component of $15.8 \pm 4.8 \mathrm{Ma}$ and an early Cretaceous age component of $105.5 \pm 5.1$ Ma (Fig. 8 and Table. 3). The young age component of $15.8 \pm 4.8 \mathrm{Ma}$ is younger than the basement AFT ages observed inside the Kokshaal Range (our data and Sobel, et al., 2006a; Fig. $3 \mathrm{~b}$ and 4), and is probably from some source areas with high exhumation rate near the range. Sample KKTM-04, from the upper part of the Pakabulake Fm. with a depositional age of 10.5 $\pm 0.5 \mathrm{Ma}$ according the paleomagnetic dating by Heermance et al. (2007), contains widespread AFT ages ranging from $3 \pm 3$ Ma to $377 \pm 113 \mathrm{Ma}$, which are not correlated to variations in $\operatorname{Dpar}_{C}$ values $(1.27-3.53 \mu \mathrm{m})$. Most grains show AFT ages 
that are older than the depositional age except one grain with AFT age of $3 \pm 3 \mathrm{Ma}$. As the AFT age of this apatite grain is much younger than the depositional age and has a very large error, it was ignored in the statistical analysis. An Oligocene age component of $31.1 \pm 18.8 \mathrm{Ma}$, an early Cretaceous age component of $100.5 \pm 20.5 \mathrm{Ma}$ and an early Jurassic age component of $190.4 \pm 20.5$ Ma were observed (Fig. 8 and Table. 3). Sample WY-02 corresponds to the bottom of the Xiyu Fm. on the southern flank of the Keketamu Anticline. The depositional age is estimated at $8.9 \pm 0.3 \mathrm{Ma}$ (Heermance et al., 2007). The wide AFT age range from $21 \pm 8$ to $193 \pm 76 \mathrm{Ma}$ observed in this sample was statistically decomposed into three age components: an Oligocene age component of $29.9 \pm 3.0 \mathrm{Ma}$, a late Cretaceous age component of 89.6 \pm 3.3 Ma and a late Jurassic age component of $168.7 \pm 3.3 \mathrm{Ma}$ (Fig. 8 and Table. 3). The $\operatorname{Dpar}_{C}$ values range from 1.43 to $4.99 \mu \mathrm{m}$, and no positive correlation can be obtained between these values and the single grain AFT ages. Sample KKTM-05 was collected higher up in the Xiyu Fm. and corresponds to a depositional age of $7.5 \pm 0.5$ Ma (Heermance et al., 2007). This sample shows again a widespread range of AFT ages between $19 \pm 7$ and $396 \pm 280$ Ma with $\operatorname{Dpar}_{C}$ values between 1.30 and $7.29 \mu \mathrm{m}$ that do not correlate to the AFT ages. A middle Eocene age component of $39.9 \pm 9.7$ Ma and an early Cretaceous age component of $145.5 \pm 3.3$ were statistically distinguished (Fig. 8 and Table. 3).

The abovementioned young age components preserved in the detrital record display a tendency to decrease with the dropping of the depositional age of samples from 15.5 
Ma in the Miocene red conglomerate to 13.7 Ma in the lower part of the Pakabulake

Fm. (Table. 3). However, the young peak age of samples from the upper part of Pakabulake Fm. and Xiyu Fm. are older than that of the samples from underneath sequences. The young age component of sample KKTM-08 is significantly younger than that of samples from both older and younger strata.

\subsection{Potential provenance and result of detrital zircon samples}

\subsubsection{Potential provenance}

As the Atushi Basin locates in the south piedmont of the SW Chinese Tian Shan and north-south paleocurrents were observed in the Cenozoic strata (Heermance et al., 2007), the Tian Shan Range is attributed to be the dominant provenance area for its Cenozoic sediment. And, the Tarim Basin to the south also provides significant sources for the deposition of the foreland basins in the Tian Shan, including the Atushi Basin (Li et al., 2010; Carroll et al., 2013; Liu et al., 2013).

A variety of $\mathrm{U}-\mathrm{Pb}$ ages were obtained from both the Precambrian plutons and sedimentary rocks in the Tarim block (Li et al., 2010; Shu et al., 2011; Carroll et al., 2013; Yang et al., 2013), and are clustered into four groups: 2360 - $2550 \mathrm{Ma}$ (peak of $2437 \mathrm{Ma}$ ), 1800 - $2020 \mathrm{Ma}$ (peak of $1870 \mathrm{Ma}$ ), 860 - $1140 \mathrm{Ma}$ (peak of $920 \mathrm{Ma}$ ) and 680 - $840 \mathrm{Ma}$ (peak of $800 \mathrm{Ma}$ ), which indicate four tectono-thermal evolution stages of the Tarim block. The first age peak at 2437 Ma represents a Neoarchean-early Paleoproterozoic magmatism of the Tarim craton corresponding to the global continent-building event (Zhang et al., 2007a, b; Long et al., 2010; Shu et al., 2011; 
Carroll et al., 2013), the second corresponds to the assemblage of the Columbia supercontinent (Daly et al., 2001; Wilde et al., 2002; Kroner et al., 2005; Santosh et al., 2006; Zhao et al., 2002), and the third and the fourth peaks are most likely related to the assemblage and break-up of the Rodinia supercontinent (Li et al., 2008, 2009). The similar tectono-thermal evolution events were also detected in the Central Tian Shan (Konopelko et al. 2009; Glorie et al., 2011).

The Palaeozoic evolution of the Tian Shan was dominated by the closure of several branches of the Paleo-Asian Ocean. The magmatic rocks, that associated to the closure of Central Tian Shan Ocean and the following accretion the Central Tian Shan block (Charvet et al., 2007), were strongly intruded into the North Tian Shan and the Central Tian Shan during the Ordovician-late Devonian. Then, the northward subduction of the South Tian Shan Ocean generated a magmatic arc along the southern edge of the Central Tian Shan during the late Devonian-early Carboniferous. After the closure of the South Tian Shan Ocean, the Hercynian post-collisional plutons (280-300 Ma) were emplaced into the South Tian Shan and the Middle Tian Shan (Konopelko et al., 2007, 2009; Glorie et al., 2011; Seltmann et al., 2011; Carroll et al., 2013) (Fig. 9).

After formation of the ancestral Tian Shan orogen, the range was characterized by a major period of tectono-magmatic quiescence during the early Mesozoic (Dumitru et al., 2001; Jolivet et al., 2010; Glorie et al., 2011; Ren et al., 2011). During the late Cretaceous-early Cenozoic, basalt was emplaced into the Tuyun Basin (Sobel and 
Arnaud, 2000; Wang et al., 2000; Ji et al., 2006; Liang et al., 2007) and along the ABT fault in our study area (Fig. 9). Considering the physiochemical resilience of the zircons, it should be pointed out that the recycled zircons from the Palaeozoic and Mesozoic strata could also be a significant provenance source for the Cenozoic Atushi Basin.

\subsubsection{Detrital zircon results}

90 zircon grains were randomly measured from the sample WY-03 that collected from the Miocene red megaclastic conglomerate, and 79 effective data points were obtained (Fig. 10, 11). U-Pb ages of this sample show a wide range between 189.8 and 2673.6 Ma and are composed by 4 main age groups: 220 - $331 \mathrm{Ma}(30.3 \%), 340$ - $500 \mathrm{Ma}$ (36.5\%), 626 - $920 \mathrm{Ma}(8.9 \%), 1556$ - $2000 \mathrm{Ma}(16.5 \%)$, which are corresponding to 4 peak ages of $301 \mathrm{Ma}, 460.6 \mathrm{Ma}, 736.4 \mathrm{Ma}$ and 1962.8 Ma (Fig.12 and Table. 4). A small age group ranging from 2230 - $2680 \mathrm{Ma}(7.6 \%)$ are observed as well. This sample is dominated by zircon groups with U-Pb peak ages of $\sim 301 \mathrm{Ma}$ and $\sim 460$ Ma.

Sample SWTS-01 was collected from the top of the Miocene red conglomerate. 85 effective age points were obtained from the sample and yield a similar age distribution with WY-04. The ages can be mainly divided into four groups of 245 $347 \mathrm{Ma}(34.1 \%), 370$ - $505 \mathrm{Ma}(35.2 \%), 764$ - $990 \mathrm{Ma}(8.2 \%)$ and 1600 - $2100 \mathrm{Ma}$ (18.8\%), with peak ages of $294 \mathrm{Ma}, 446.6 \mathrm{Ma}, 984 \mathrm{Ma}$ and $1808 \mathrm{Ma}$, respectively (Fig. 11, Table. 4). Most zircon grain ages fall between $~ 250 \mathrm{Ma}$ and $~ 500 \mathrm{Ma}$. 
As only 27 effective age points were obtained from KKTM-08 (the bottom of the

Pakabulake Fm.), the sample shows no obvious primary age peaks or a faint age peak of 607 Ma. Despite its limited zircon grains, the sample shows a wide age range between $15 \mathrm{Ma}$ and $2409 \mathrm{Ma}$, which contains 18 Precambrian ages (66.7\%), 4 early Palaeozoic ages (14.8\%), 2 late Palaeozoic ages (7.4\%), 2 Mesozoic ages (7.4\%) and a very young Miocene age (15 Ma) (Fig. 11). Very different from other samples, this sample contains a higher percentage of Precambrian ages. However, given the insufficient zircon grains, the high content of Precambrian ages might be not credible enough. The youngest zircon age $(15 \pm 1.08 \mathrm{Ma})$ is nearly the same time as the depositional age the strata (13.7 Ma).

75 effective age points obtained from KKTM-04 that collected from the upper part of the Pakabulake Fm. show a widely range between 174 Ma and 2527 Ma (Fig. 11). Four zircon age peaks can be detected. Two primary peaks are located at $284 \mathrm{Ma}$ $(25.3 \%)$ and $435 \mathrm{Ma}(34.7 \%)$, and two secondary age peaks occur at $608 \mathrm{Ma}(607$ $684 \mathrm{Ma} 8 \%)$ and $1820 \mathrm{Ma}(25.3 \%)$.

104 effective age points were obtained from WY-02 (the bottom of the Xiyu Fm.). $\mathrm{U}-\mathrm{Pb}$ ages of this sample show a wide range between 44.9 and $2541.7 \mathrm{Ma}$, and can be mainly separated into five groups: 240 - $350 \mathrm{Ma}(24.0 \%), 396$ - $543 \mathrm{Ma}(39.4 \%)$, 785 - $863 \mathrm{Ma}(7.7 \%), 1554$ - $1935 \mathrm{Ma}(18.3 \%)$ and 2196 - $2542 \mathrm{Ma}(6.7 \%)$ with their peak ages of $316 \mathrm{Ma}, 418 \mathrm{Ma}, 816 \mathrm{Ma}, 1818 \mathrm{Ma}$ and $2469 \mathrm{Ma}$, respectively (Fig. 11). Zircon grains with Cenozoic ages (44.9 - $48.5 \mathrm{Ma})$ appear again in this sample 
and are magmatic original.

79 effective age points obtained from KKTM-05 (Xiyu Fm.) show a wide range between $243 \mathrm{Ma}$ and $2614 \mathrm{Ma}$ with $\mathrm{Th} / \mathrm{U}$ value of $0.06-2.47$ (Fig. 11). The U-Pb ages are clustered into 5 groups: 243 - $342 \mathrm{Ma}(27.8 \%), 384$ - $486 \mathrm{Ma}(25.3 \%), 609$ $985 \mathrm{Ma}(16.5 \%), 1308$ - $1958 \mathrm{Ma}(21.5 \%), 2248$ - $2685 \mathrm{Ma}(8.9 \%)$ with their corresponding peak ages of $301 \mathrm{Ma}, 452 \mathrm{Ma}, 840 \mathrm{Ma}, 1711 \mathrm{Ma}$ and $2434 \mathrm{Ma}$, respectively.

In summary, all Cenozoic samples display wide age ranges and similar age distribution, except for sample KKTM-08 (lower Pakabulake Fm.) that contains insufficient crystals (Fig. 11). The detrital zircon ages are characterized by two primary age peak at 288 - $300 \mathrm{Ma}$ and 420 - $460 \mathrm{Ma}$, two secondary peaks around 840 Ma and $1820 \mathrm{Ma}$ and sometimes a small peak at 600 - 620 Ma. Similar detrital zircon $\mathrm{U}-\mathrm{Pb}$ age distributions were also reported from the Cenozoic sedimentary rocks in Kuqa and Wuqia area in the South Tian Shan (Li et al., 2010; Carroll et al., 2013; Liu et al., 2013; Yang et al., 2013). The two primary peaks most likely correspond to the Hercynian post-collisional magmatism in the South and Central Tian Shan and Ordovician-late Devonian magmatism in the North and Central Tian Shan, respectively, and the Precambrian age components are probably related to the Tarim block or the Central Tian Shan (Carroll et al., 2013; Liu et al., 2013). Zircons with early Cenozoic U-Pb ages in WY-2 are most probably come from the late Cretaceous Eocene basalt in the study area (Sobel and Arnaud, 2000; Ji et al., 2006). As no 
mid-Miocene magmatic activation were reported in the study area and surrounding regions, the $15 \mathrm{Ma}$ zircon grain was likely transported by volcanic ashes from a remote source area.

In contrast with the detrial AFT data, no significant provenance change can be detected in the Cenozoic sedimentary rocks despite the appearance of the Cenozoic zircons in KKTM-08 and WY-02. All the Cenozoic samples exhibit wide detrial U-Pb age ranges. Similar U-Pb age distribution was observed in the Jurassic and Cretaceous sandstones in the Ulugqat area $30 \mathrm{~km}$ west to the Atushi Basin by Yang et al., (2013) and they attribute the wide zircon U-Pb age distribution to a huge river system and the flat topography of the Tian Shan in the Mesozoic. Carroll et al. (2013) suggested that the extensive Palaeozoic sandstone supplied significant sources of recycled zircon for the Mesozoic and Cenozoic sedimentary rocks in north of the Tarim Basin. Therefore, the wide detrital $\mathrm{U}-\mathrm{Pb}$ age ranges can be either caused by a vast source area that encompassing most of the tectonic blocks of Tian Shan or by recycling of previous sedimentary rocks containing those zircons. As the building of the modern Tian Shan began at the Oligocene-Miocene boundary (Sobel et al., 1997, 2006a; Glorie et al,. 2011; our data), the flat Mesozoic topography and the river system should be disturbed and rebuilt (Fig. 13), and the wide U-Pb age distributions of the Cenozoic samples in the study area are more likely caused by zircon recycling from previous sedimentary rocks. 


\section{Discussion}

\subsection{Cenozoic tectono-geomorphological evolution of the SW Chinese Tian Shan}

As a response to distant collision of continental blocks with the southern margin of Asia, the Tian Shan Range experienced a complex uplift history during the Cenozoic (Molnar and Tapponnier, 1975; Hendrix et al., 1992; Dumitru et al., 2001; Jolivet et al., 2010; Macaulay et al., 2014). While the Mesozoic and early Tertiary exhumation was largely controlled by the inherent lithospheric structures, a late Oligocene-early Miocene exhumation phase throughout the whole range was constrained by AFT data and sedimentological analyses (e.g., Hentrix et al., 1994; Yin et al., 1998; Trifonov et al., 2008). In this study, the basement AFT samples in this study suggest a late Eocene-Oligocene reheating episode of the Kokshaal Range. A $25-70^{\circ}$ Creheating episode is detected in the sample TK-09 and TK-10 that located within $2 \mathrm{~km}$ in front of the Maidan fault. And, the similar reheating process was also detected by thermal modelling of the sample 99WT-3 by Sobel et al. (2006a), which is about $7 \mathrm{~km}$ south to the Maidan fault and $20 \mathrm{~km}$ away from the sample TK-09, as well as in the Kyrgyz Range and Atbashi Range (Sobel et al., 2006b; Glorie et al., 2011). It can be caused by either the tectonic burying of hanging walls of thrust faults or sediment loading (Sobel et al., 2006a). Previous study suggested that the reheating event in the Atbashi Range was due to an increase in sediment loading caused by renewed erosion of a growing topography (Glorie et al., 2011). If the late Eocene-Oligocene reheating process in the study area was due to sediment loading and the regional geothermal 
gradient is $22^{\circ} \mathrm{C} / \mathrm{km}$ (Zhang, 1989; Sobel and Dumitru, 1997), the thickness of the sediment should reach 1000-3200 m in the Kokshaal Range. However, we have not found any Cenozoic sedimentary rocks in the modern Kokshaal Range. In contrast with the south flank of the Kokshaal Range, the low-relief surface preserved on the north flank of the Kokshaal Range experienced a stable thermal history since the late Jurassic (Glorie et al., 2011). The oldest Cenozoic sediment in the Atushi Basin shows a paleomagnetic age of $18 \mathrm{Ma}$ (Heermance et al., 2007). Hence, the sediment burying was occurred locally on the south flank of range if the reheating event was driven by increase in sediment loading in the study area. In this case, we infer the sediment loading was likely caused by erosion of a nearby growing topography. Alternatively, the reheating event was caused by the tectonic burying of the hanging wall of the Maidan fault. Therefore, the reheating event implies the initiation of the thrusting activation of the Maidan fault or a topographical growth of the Kokshaal Range at 35 -25 Ma. The contemporaneous uplift of the Pamir was also detected based on the coarse molasse deposits in the northeastern Pamir and foreland basin deposits in the Tajik Basin and southern Tian Shan (Sun et al., 2013; Carrapa et al., 2015). Hence, the 35 - 25 Ma reheating events in the study area is likely a response to the Cenozoic tectonic uplift of the Pamir.

After the reheating at 35 - $25 \mathrm{Ma}$, the sample TK-09 and TK-10 located in the hanging wall of the Muziduke fault experienced a rapid cooling episode from $15 \pm 5$ Ma to present, suggesting a strong exhumation event of the Kokshaal Range in the 
mid-Miocene. A similar cooling event was reported from the sample 99WT-3, over 7 km south of the Maidan fault (Sobel et al., 2006a), and late Oligocene-Miocene AFT ages were also observed on the hanging wall of the Muziduke fault (Sobel et al., 2006a and our data). Although Sobel et al. (2006a) inferred that the exhumation of the Kokshaal Range initiated at $\sim 24$ Ma based on these young AFT ages, the limited confined tracks in these sample show short track lengths and imply that these samples could also be exhumed from the PAZ (Sobel et al., 2006a). So far, the denudation of the Muziduke fault might initiate around $15 \pm 5$ Ma. Our thermal modelling results indicate that a $60-80{ }^{\circ} \mathrm{C}$ cooling occurred in the recent $\sim 15$ Ma. Assuming a surface temperature of $10{ }^{\circ} \mathrm{C}$ and a geothermal gradient of $22 \pm 3{ }^{\circ} \mathrm{C} / \mathrm{km}$ (Zhang, 1989; Sobel et al., 2006a), we can estimate that the mean exhumation rate of the Kokshaal Range is $0.18-0.28 \mathrm{~mm} / \mathrm{yr}$. Similarly, Sobel et al. (2006a) have also calculated an exhumation rate of $0.2-0.3 \mathrm{~mm} / \mathrm{yr}$ between 18 and $3 \mathrm{Ma}$ in the study region based on the AFT analyses of late Cenozoic sediments. Further south, the activation of ABT occurred nearly the same time as constrained by Heermance et al. (2007, 2008). Hence, we infer that the simultaneous activation of the Muziduke fault and ABT is most likely corresponding to the strong exhumation phase of the Kokshaal Range in the middle Miocene. The similar mid-Miocene cooling event was also detected in the Aksu blue schist and the Kyrgyz Tian Shan north to the Alai Basin (De Grave et al., 2012; Zhang et al., 2009). Fission track dating also suggested that deformation propagated southward from the Tian Shan to Kuzigongsu since ca. 14 Ma (Sobel and 
Dumitru, 1997). Moreover, sharp increase in sedimentary rate in the northern and southern Tarim Basin also suggests the thrusting speeded up in the middle Miocene (15-13.7 Ma) (Yin et al., 2002; Wang et al., 2003; Sun et al., 2005; Huang et al., 2006; Wu et al., 2012). Therefore, the exhumation of the Kokshaal Range at ca. 15 Ma is consistent with the regional uplift in Tian Shan and southern margin of the Tarim Basin in the mid-Miocene.

Detrital apatite grains from the late Cretaceous Kezilesu Group yield a late Triassic to early Jurssic AFT central age (our study and Sobel et al., 2006a), which can also be found on the hanging wall of the Muziduke fault (TK-10) and in Permian sedimentary rock in the piedmont basin (Sobel et al., 2006a and Fig 4). Therefore, the late Trassic early Jurassic AFT ages in the foreland basin can be produced by either erosion of the Tian Shan Range to the north or recycling of Permain sedimentary sequences. The unreseted AFT ages suggest that the Cretaceous depositions might be buried to less than $4 \mathrm{~km}$ before exhumated to the surface. However, more than $6 \mathrm{~km}$ Neogene to Quarternary sedimentary sequences developed in the Atushi Basin (Heermance, et al., 2007). Hence, a topography in the Atushi Basin likely appeared before Neogene, which is supported by the angular unconformable contact between the Cretaceous and Cenozoic sequences. As no obvious reheating were observed in the Cretaceous sedimentary rocks, we infer that younger sedimentary rocks overlying on it also did not experience any evident reheating. Late Triassic to early Jurassic age components were also found from Miocene detrital samples: $219.9 \pm 7.4$ Ma (WY-03), $226.3 \pm$ 
13.7 Ma (SWTS-01), 184.4 \pm 11.0 Ma (SWTS-02) and 190.4 \pm 20.5 Ma (KKTM-04), which were likely produced by either erosion of the Kokshaal Range or recycling of Permian and Cretaceous sandstone. The detrital zircon analysis also shows that the recycling of the Palaeozoic and Mesozoic rocks contributed a significant part for the Cenozoic sedimentation in the Atushi Basin.

The young detrital AFT age component of the Cenozoic sedimentary rocks gradually decreases from $39.9 \pm 9.7$ in the Miocene red conglomerate to $15.8 \pm 4.8 \mathrm{Ma}$ at the bottom of the Pakabulake Fm. with the reduction of the depositional age (Fig. 12). The lag time decreased rapidly from $\sim 15$ Ma to $\sim 2$ Ma, suggesting an intensive erosion event in source areas, and the corresponding erosion rate sharply increased from $\sim 0.28 \mathrm{~mm} / \mathrm{yr}$ to $\sim 2.5 \mathrm{~mm} / \mathrm{yr}$. Similar detrital AFT ages between 25.0 and 13.1 Ma were also observed in the Wenguri area by Sobel et al. (1997) and they inferred that these ages probably reflect the activation of nearby thrusts. Then, the AFT component age abruptly increases to $31.6 \pm 18.8 \mathrm{Ma}$ in the upper part of Pakabulake Fm. and decrease again. Another abrupt increase of young AFT peak ages can be detected in the lower part of Xiyu Fm. The disturbance of the positive relationship between the young AFT peak ages and the depositional ages can be either caused by tectonic activation in source areas or provenance changes.

The paleocurrent direction from the north to south in the Atushi Basin indicated the Tian Shan is the main source area for the Cenozoic sedimentary rocks in the study area (Heermance et al., 2007). Therefore, the detrital AFT ages in Miocene 
conglomerate and the lower part of Pakabulake Fm. must be a reflection of a denudation of the Tian Shan Range. Although previous AFT study stated that the young age components probably due to the thrusting activation nearby (Sobel et al., 1997), the sample KKTM-08 contains AFT ages younger $(15.8 \pm 4.8 \mathrm{Ma})$ than any basement AFT ages in the Kokshaal Range (Sobel et al., 2006a; our data and Fíg. 5). However, basement ages of 20 - 10 Ma were observed in the Atbashi Range located $100 \mathrm{~km}$ north to the study area and a rapid cooling phase from the closure temperature to $\sim 50^{\circ} \mathrm{C}$ was also occurred between $\sim 10$ to $8 \mathrm{Ma}$ in the STSs (AI-13 and Kyr-21 in Glorie et al., 2011). Hence, the Atbashi Range was probably one of the significant source regions of the Atushi Basin. And, the Atushi Basin was still connected with the Aksai Basin before the mid-Miocene (Fig. 13b), though the thrusting of faults or topographical growth in the Kokshaal Range has already initiated at ca. 35 - $25 \mathrm{Ma}$. However, the young AFT peak age suddenly increased and the mid-Miocene AFT peak age no longer existed in the upper part of Pakabulake Fm. (KKTM-04), which probably implies that Atbashi Range was not the source area of the Atushi Basin since the mid-Miocene. We infer that a high topography of the Kokshaal Range was generated from the rapid uplift in the mid-Miocene, which blocked all the southward rivers flowed from the Atbashi Range to the Atushi Basin. The Atushi Basin and the Aksai Basin were finally separated into two independent basins (Fig. 13c).

The young AFT peak age (39.9 $\pm 9.7 \mathrm{Ma})$ increases again in Xiyu Fm. (KKTM-05) (Fig. 12). We infer that it represents the recycling of the Cenozoic sediments from the 
foreland area, which was likely caused by a late Miocene basinward propagation of the shortening deformation. Heermance et al. (2008) suggested that the ABT, Tashipishake and Keketamu anticlines were deformed at 15 Ma, 13.5 Ma and 4.7 Ma, respectively. Cenozoic sedimentary sequences, which were titled during the shortening deformation, were recycled and deposited further south. Clast composition data show that yellow and red sandstone pebble content increased from the lower part of the Xiyu conglomerate to the middle part of it as the dip angle of the growth strata decreases, indicating the recycling of the strata in the piedmont basin. What's more, the growth strata initiated ca. 4.7 Ma on the south flank of the Keketamu Anticline also suggests the Pliocene shortening deformation in the Atushi Basin (Heermance et al., 2007). Similarly, Sun et al. (2007, 2009a, 2009b) indicated that growth strata initiated ca. 6 Ma developed on both northern and southern piedmonts of the Tian Shan and the southern Tarim Basin, and they suggested that these coeval widespread growth strata representing a strong latest Miocene to early Pliocene crustal shortening episode in the Tian Shan and the northern Tibet. Numerous AFT/AHe ages of the Tian Shan basement together with magnetostratigraphic data of Neogene sedimentary sequences in the adjacent basins have revealed a late Miocene exhumation pulse between 10 - 3 Ma (Charreau et al., 2006; Sun et al., 2007; Heermance et al., 2008; De Grave et al., 2012; Glorie et al., 2012). Detrital AFT analysis in this study suggests that the shortening deformation of Atushi Basin in late Miocene is probably corresponds to a regional late Miocene intense shortening episode and basinward 
propagating deformation of the Tian Shan. Finally, the shortening deformation propagated further south the Atushi anticline at 1.4 - 1.2 Ma (Chen et al., 2002).

While both the growth strata in previous studies and the recycled detrital AFT in the Xiyu Fm. imply a basinward propagation of the deformation, the constant lag times of the late Cenozoic sediment along the Atushi-Talanghe anticline indicate a stable exhumation rate in the source area between 18 and $3 \mathrm{Ma}$ (Sobel et al., 2006a and Fig. 12).

5.2. Tectonic kinematics of the SW Chinese Tian Shan and the southern termination of the TFF

The India-Asia collision not only caused the intense uplift of the Tibet Plateau and reactivation of the Tian Shan belt, but also leaded to the activation of a series of huge strike-slip faults such as the Altyn Tagh fault, East Kunlun fault and Talas-Fergana fault (TFF). These continental strike-slip faults play a significant role in accommodating the strong crustal shortening and are often terminated by extensional or contractional imbricated faults or horsetail splays (Molnar and Tapponnier, 1975; Yin, 2010). As the largest strike-slip fault system of the Tian Shan, the TFF experienced episodes of strike-slip motion in Palaeozoic and Jurassic constrained by ${ }^{40} \mathrm{Ar} /{ }^{39} \mathrm{Ar}$ dating of the syn-kinematic white mica (Rolland et al., 2013) and was reactivated in late Cenozoic with an amount of right-lateral slip of at least $60 \pm 10 \mathrm{~km}$ (Verzilin, 1968). However, it is still debatable whether the fault terminates in the Atushi Basin or it extends southward to the Pamir region (Luo et al., 2004; Li et al., 
2007). The tectonic evolution of the Atushi Basin is significantly influenced by this dextral strike-slip fault since late Triassic and Jurassic (Sobel, 1999; Luo et al., 2004). Sedimentary study suggested that a middle Jurassic transtensional basin was controlled by the TFF and the paleo West Kunlun fault (Sobel, 1999). Our mapping from satellite imagery also shows that the thrust faults of the Kokshaal Range are likely linked to the dextral TFF (Fig. 1). Furthermore, it can be clearly observed from satellite images that the large strike-slip fault spatially connects with many NEE-trending sub-ranges of the Tian Shan and transferred into a series of thrusts on its both sides, which was intepreted as transpressional pop-up structures of the TFF (Bande et al, 2014, 2015). The paleomagnetic study also suggested that the eastern wall of the TFF transferred to a series of southward thrust fault approximately perpendicular to the TFF at the south margin of the south Chinese Tian Shan (Huang et al., 2008). Therefore, the thrust faulting of the Kokshaal Range might be transformed from the dextral strike-slip faulting of the TFF.

Burtman et al., (1996) suggest that the Cenozoic deformation of the TFF initiated in 12.5 - 4 Ma based on geomorphological analyses. Moreover, a mid-Miocene rapid cooling was also observed in a branch fault of the TFF north to the Tuoyun basin (Glorie et al., 2011). AFT data from this study also show a rapid exhumation of the Kokshaal Range in the same period, which reinforces the speculation that the thrust system of the Kokshaal Range and the Atushi Basin is kinematically linked with the TFF and forms the contractional imbricated faults at the southernmost termination of 
this large dextral strike-slip fault. In this case, the $15 \pm 5$ Ma cooling event of the Kokshaal Range is probably a response to the Cenozic dextral movement of the large strike-slip fault. As discussed in the above section, the middle Miocene deformation was occurred all around the Tarim Basin. The late Cenozoic movement of the TFF and its transferred faults appear to be a response to this middle Miocene regional deformation. While previous low-temperature thermochronology data indicate that the Cenozoic deformation of the Tian Shan varies from south to north due to the northward propagation of the deformation (e.g., Bullen et al., 2001; Jolivet et al., 2010), a 25 Ma exhumation event was synchronously occurred along the TFF both in the NW and SW Tian Shan (Bande et al., 2014, 2015). They also suggested that the huge pre-existing strike-slip fault played a significant role for transferring the Pamir induced shortening deformation of the Tian Shan (Bande et al., 2014, 2015). Although the initiation of the Cenozoic deformation of the TFF is still debatable, the thrust and fold system in the study area was likely transferred from this large strike-slip fault.

\section{Conlusions}

The synthesis of our detailed geological and geomorphological mapping from satellite images, field observations, AFT and detrital zircon data together with previous data provide a better understanding of the Cenozoic tectono-geomorphological growth of the SW Chinese Tian Shan. Major conclusions are listed as follow:

1) The tectonic deformation exhibits a tendency of southward migration. Our new 
thermal modelling shows that the initiation of the Cenozoic deformation of the Maidan fault or the topographical growth of the Kokshaal Range occurred in late Eocene-Oligocene (35-25 Ma), which is slightly earlier than that late Oligocene to early Miocene ( $24 \mathrm{Ma}$ ) range uplift event suggested by the previous studies. It is probably a response of the Tian Shan to the northward indentation and growth of the Pamir. Then, the structural deformation migrated southward to the Muziduke fault and the ABT at $15 \pm 5$ Ma. Finally, the shortening deformation propagated basinward to the fault-related folds in the late Miocene.

2) Similarly, the geomorphological analysis shows that the Atsuhi Basin was still connected with the Aksai Basin during the early Miocene. They were separated into two independent basins since the mid-Miocene because of the rapid uplift of the Kokshaal Range.

3) The thrust and folds system in the study area are kinematically linked with the TFF. The late Cenozoic thrust faults of the SW Chinese Tian Shan are likely transferred from the dextral TFF since $\sim 15 \mathrm{Ma}$. 


\section{Acknowlegements}

This research was supported by the National Natural Science Foundation of China (NSFC Project No. 4132214) and the "Strategic Priority Research Program" of the Chinese Academy of Sciences (XDB03020200). We especially thank to Dr.Gallagher for his useful help to simulation of the AFT dating data and Dr Jimin Sun for his help for the field work and valuable discussion. We also appreciate to Drs. Sobel and Dr Guangwei Li for constructive comments that improved the manuscript largely, and Mr. Genwen He for his assiatnace during the sampling and mineral sepration. 


\section{References}

Abdrakhmatov, K.Y., Aldazhanov, S.A., Hager, B.H., Hamburger, M.W., Herring, T.A., Kalabaev, K.B., Makarov, V.I., Molnar, P., Panasyuk, S.V., Prilepin, M.T., Reilinger, R.E., Sadybakasov, I.S., Souter, B.J., Trapeznikov, Y.A., Tsurkov, V.Y., and Zubovich, A.V., 1996. Relatively recent construction of Tien Shan inferred from GPS measurements of presentday crustal deformation rates. Nature 384, $450-453$.

Allen, M.B., and Windley, B.F., 1993. Evolution of the Turfan Basin, Chinese Central Asia. Tectonics 12, 889-896.

Allen, M.B., Vincent, S.J., and Wheeler, P.J., 1999. Late Cenozoic tectonics of the Kepingtage thrust zone: Interactions of the Tien Shan and Tarim Basin, northwest China. Tectonics 18, 639-654.

Avouac, J.P., Tapponnier, P., Bai, M., You, H., and Wang, G., 1993. Active thrusting and folding along the Northern Tien Shan and Late Cenozoic rotation of the Tarim relative to Dzungaria and Kazakhstan. Journal of Geophysical Research 98, 773-807.

Bande, A., Sobel, E., and Mikolaichuk, A., 2014. Cenozoic tectonic history of the Western Tien Shan constrained by low-temperature thermochronology. European Geosciences Union, Geophysical Research Abstract 16.

Bande, A., Sobel, E., Mikolaichuk, A., and Torres, A. V., 2015. Talas-Fergana Fault Cenozoic timing of deforming and its relation to Pamir indentation, in Geology 
evolution of Central Asian Basins and the Tien-Shan Range, edited by Brunet M-F,

McCann T., and Sobel E. R. (in press).

Barbarand, J., 2003. Compositional and structural control of fission-track annealing in apatite. Chemical Geology 198, 107-137.

Bullen, M.E., Burbank, D.W., Garver, J.I., and Abdrakhmatov, K.Y., 2001. Late Cenozoic tectonic evolution of the northwestern Tien Shan: New age estimates for the initiation of mountain building. Geological Society of America Bulletin 113, $1544-1559$.

Burbank, D.W., Mclean, J.K., Bullen, M., Abdrakhmatov, K.Y., and Miller, M.M., 1999. Partitioning of intermontane basins by thrust-related folding, Tien Shan, Kyrgyzstan. Basin Research 11, 75-92.

Bureau of Geology and Minreal Resources of Xinjiang Uygur Autonomous Region (BGMRXJ), 1993. Regional Geology of Xinjiang Uygur Autonomous Region. Geological Publishing House, Beijing, 1, 242-243 (in Chinese with English abstract).

Burtman, V.S., Skobelev, S.F., and Molnar, P., 1996. Late Cenozoic slip on the Talas-Fergana fault, the Tien Shan, central Asia. Geological Society of America Bulletin 108, 1004-1021.

Burtman, V.S., 2012. Geodymanics of Tibet, Tarim, and the Tien Shan in the Late Cenozoic. Geotectonics 46, 185-211.

Carlson, W.D., Donelick, R.A., and Ketcham, R.A., 1999. Variability of apatite 
fission-track annealing kinetics: I. Experimental results. Ametican Mineralogist 84, 1213-1223.

Carrapa, B., DeCelles, P.G., Wang, X., Clementz, M.T., Mancin, N., Stoica, M., Kraatz, B., Meng, J., Abdulov, S., and Chen, F., 2015. Tectono-climatic implications of Eocene Paratethys regression in the Tajik basin of central Asia. Earth and Planetary Science Letters 424, 168-178.

Carroll, A.R., Dumitru, T.A., Graham, S.A., and Hendrix, M.S., 2013. An 800 million-year detrital zircon record of continental amalgamation: Tarim basin, NW China. International Geology Review 55, 818-829.

Chang, J., Qiu, N.S., and Li, J.W., 2012. Tectono-thermal evolution of the northwestern edge of the Tarim Basin in China: Constraints from apatite (U-Th)/He thermochronology. Journal of Asian Earth Sciences 61, 187-198.

Charreau, J., Gilder, S., Chen, Y., Domiguez, S., Avouac, J.P., Sen, S., Jolivet, M., Li Y., and Wang, W., 2006. Magnetostratigraphy of the Yaha section, Tarim Basin (China): $11 \mathrm{Ma}$ acceletation in erosion and uplift of the Tian Shan mountains. Geology 34, 181-184.

Charvet, J., Shu, L., Laurent-Charvet, S., Wang, B., Faure, M., Cluzel, D., Chen, Y., and Jong, K., 2011. Palaeozoic tectonic evolution of the Tianshan belt, NW China. Science China Earth Sciences 54, 166-184.

Chen, J., Ding, G.Y., Burbank, D.W., Scharer, K.M., Rubin, C., Sobel, E., Qu, G.S., Shen, J., Yin, J.H., and Zhao, R.B., 2001. Late Cenozic tectonics and seismicity in 
the Southwestern Tian Shan, China. Earthquake Research in China 17, 134-155 (in

Chinese with English abstract).

Chen, J., Burbank, D.W., Scharer, K.M., Sobel, E., Yin, J.H., Ruibin, C., and Zhao, R.B., 2002. Magnetochronology of the Upper Cenozoic strata in the Southwestern Chinese Tian Shan: rates of Pleistocene folding and thrusting. Earth and Planetary Science Letters 195, 113-130.

Chen, J., Heermance, R., Burbank, D.W., Scharer, K.M., Miao, J.J., and Wang, C.S., 2007. Quantification of growth and lateral propagation of the Kashi anticline, southwest Chinese Tian Shan. Journal of Geophysical Research 112, 1-22.

Cobbold, P.R., Sadybakasov, E., and Thomas, J.C., 1996. Cenozoic transpression and basin development, Kyrgyz Tien Shan, central Asia, in Geodynamic Evolution of Sedimentary Basins, edited by F. Roure et al., 181-202, Editions Technip, Paris.

Daly, J.S., Balagansky, V.V., Timmerman, M.J., Whitehouse, M.J., Jong, K.d., Guise, P., Bogdanova, S., Gorbatschev, R., and Bridgwater, D., 2001. Ion microprobe $\mathrm{U}-\mathrm{Pb}$ zircon geochronology and isotopic evidence for a trans-crustal suture in the Lapland-Kola Orogen, northern Fennoscandian Shield. Precambrian Research 105, 289-314.

De Grave, J., Buslov, M.M., and Van den haute, P., 2007. Distant effects of India-Eurasia convergence and Mesozoic intracontinental deformation in Central Asia: Constraints from apatite fission-track thermochronology. Journal of Asian Earth Sciences 29, 188-204. 
De Grave, J., Glorie, S., Buslov, M.M., Izmer, A., Fournier-Carrie, A., Batalev, V.Y., Vanhaecke, F., Elburg, M., and Van den haute, P., 2011. The thermo-tectonic history of the Song-Kul plateau, Kyrgyz Tien Shan: Constraints by apatite and titanite thermochronometry and zircon $\mathrm{U} / \mathrm{Pb}$ dating. Gondwana Research 20, $745-763$.

De Grave, J., Glorie, S., Ryabinin, A., Zhimulev, F., Buslov, M.M., Izmer, A., Elburg, M., Vanhaecke, F., and Van den haute, P., 2012. Late Palaeozoic and Meso-Cenozoic tectonic evolution of the southern Kyrgyz Tien Shan: Constraints from multi-method thermochronology in the Trans-Alai, Turkestan-Alai segment and the southeastern Fergana Basin. Journal of Asian Earth Sciences 44, 149-168.

De Grave, J., Glorie, S., Buslov, M.M., Stockli, D.F., McWilliams, M.O., Batalev, V.Y., and Van den haute, P., 2013. Thermo-tectonic history of the Issyk-Kul basement (Kyrgyz Northern Tien Shan, Central Asia). Gondwana Research 23, 998-1020.

Donelick, R.A., Ketcham, R.A., and Carlson, W.D., 1999. Variability of apatite fission-track annealing kinetics: II. Crystallographic orientation effects. American Mineralogist 84, 1224-1234.

Donelick, R.A., O'Sullivan, P.B., and Ketcham, R.A., 2005. Apatite Fission-Track Analysis. Reviews in Mineralogy \& Geochemistry 58, 49-94.

Dumitru, T.A., Zhou, D., Chang, E.Z., and Graham, S.A., 2001. Uplift, exhumation, and deformation in the Chinese Tian Shan. Geological Society of America Memior 
194, 71-99.

Fu, B.H., Lin, A.M., Kano, K., Maruyama, T., and Guo, J.M., 2003. Quaternary folding of the eastern Tian Shan, northwest China. Tectonophysics 369, 79-101.

Fu, B.H., Ninomiya, Y., and Guo, J.M., 2010. Slip partitioning in the northeast Pamir-Tian Shan convergence zone. Tectonophysics 483, 344-364.

Fu, B.H., Walker, R., and Sandiford, M., 2011. The 2008 Wenchuan earthquake and active tectonics of Asia. Journal of Asian Earth Sciences 40, 797-804.

Gallagher, K., Charvin, K., Nielsen, S., Sambridge, M., and Stephenson, J., 2009. Markov chain Monte Carlo (MCMC) sampling methods to determine optimal models, model resolution and model choice for earth science problems. Marine and Petroleum Geology 26, 525-535.

Gallagher, K., 2012. Transdimensional inverse thermal history modeling for quantitative thermochronology. Journal of Geophysical Research 117, doi:10.1029/2011JB008825.

Gao, J., Long, L.L., Klemd, R., Qian, Q., Liu, D.Y., Xiong, X.M., Su, W., Liu, W., Wang, Y.T., and Yang, F.Q., 2008. Tectonic evolution of the South Tianshan orogen and adjacent regions, NW China: geochemical and age constraints of granitoid rocks. International Journal of Earth Sciences 98, 1221-1238.

Gao, R., Hou, H.S., Cai, X.Y., Knapp, J.H., He, R.Z., Liu, J.K., Xiong, X.S., Guan, Y., Li, W.H., Zeng, L.S., and Roechker, W., 2013. Fine crustal structure beneath the junction of south-west Tian Shan and Tarim Basin, NW China. Lithosphere 5, 
$382-392$.

Glorie, S., De Grave, J., Buslov, M.M., Elburg, M.A., Stockli, D.F., Gerdes, A., and Van den haute, P., 2010. Multi-method chronometric constraints on the evolution of the Northern Kyrgyz Tien Shan granitoids (Central Asian Orogenic Belt): From emplacement to exhumation. Journal of Asian Earth Sciences 38, 131-146.

Glorie, S., De Grave, J., Buslov, M.M., Zhimulev, F.I., Stockli, D.F., Batalev, V.Y., Izmer, A., Van den haute, P., Vanhaecke, F., and Elburg, M.A., 2011. Tectonic history of the Kyrgyz South Tien Shan (Atbashi-Inylchek) suture zone: The role of inherited structures during deformation-propagation. Tectonics 30, doi:10.1029/2011TC002949.

Green, P.F., 1985. Comparison of zeta calibration baselines for fission-track dating of apatite, zircon and sphene. Chemical Geology 58, 1-22.

Heermance, R.V., Chen, J., Burbank, D.W., and Wang, C.S., 2007. Chronology and tectonic controls of LateTertiary deposition in the southwesternTian Shan foreland, NWChina. Basin Research 19, 599-632.

Heermance, R.V., Chen, J., Burbank, D.W., and Miao, J.J., 2008. Temporal constraints and pulsed Late Cenozoic deformation during the structural disruption of the active Kashi foreland northwest China. Tectonics 27, doi:10.1029/2007TC002226.

Hendrix, M.S., Graham, S.A., Carroll, A.R., Sobel, E.R., McKnight, C.L., Schulein, B.J., and Wang, Z.X., 1992. Sedimentary record and climatic implications of recurrent deformation in the Tian Shan: Evidence from Mesozoic strata of the 
north Tarim, south Junggar, and Turpan basins, northwest China. Geological Society of America Bulletin 104, 53-79.

Hendrix, M.S., Dumitru, T.A., and Graham, S.A., 1994. Late Oligeocene-early Miocene unroofing in the Chinese Tianshan: An early effect of the India-Asia collision. Geology 22, 487-490.

Huang, B.C., Piper, D.A., Peng, S.T., Liu, T., Li, Z., Wang, Q.C., and Zhu, R.X., 2006. Magnetostratigraphic study of the Kuche Depression, Tarim Basin, and Cenozoic uplift of the Tian Shan Range, Western China. Earth and Planetary Science Letters $251,346-364$.

Huang, B.C., Piper, D.A., Zhu R.X., 2009. Paleomagnetic constraints on neotectonic deformation in the Kashi depression of the western Tarim Basin, NW China. The International Journal of Earth Sciences 98, 1469-1488.

Hou, H.S., Gao, R., He, R.Z., Cai, X.Y., Liu, J.K., Xiong, X.S., Guan, Y., Zeng, L.S., Knapp, H. J., and Roecker, S., 2012. Shallow-deep relationship for the junction belt of western part of South Tianshan and Tarim basin-Revealed from preliminary processed deep seismic reflection profile. Chinese Journal of Geophysics 55, 4116-4125 (in Chinese with English abstract).

Hurford, A.J., and Green, P.F., 1983. The zeta age calibration of fission-track dating. Chemical Geology 41, 285-317.

Hurford, A.J., 1990. Standardization of fission track dating calibration: Recommendation by the Fission Track Working Group of the I.U.G.S. 
Subcommission on Geochronology. Chemical Geology 80, 171-178.

Jasra, A., Holmes, C.C., and Stephens, D.A., 2005. Markov Chain Monte Carlo Methods and the Label Switching Problem in Bayesian Mixture Modeling. Statistical Science 20, 50-67.

Ji, J.Q., Han, B.F., Zhu, M.F., Chu, Z.Y., and Liu, Y.L., 2006. Cretaceous-Paleogene alkaline magmatism in Tuyon, southwest Tianshan mountains: geochronology, petrology and geochemistry. Acta Petrologica Sinica 22, 1324-1340 (in Chinese with English abstract).

Jolivet, M., Brunel, M., Seward, D., Xu, Z.Q., Yang, J., Roger, F., Tapponnier, P., Malavieille, J., Arnaud, N., and Wu, C., 2001. Mesozoic and Cenozoic tectonics of the northern edge of the Tibetan plateau: fission-track constraints. Tectonophysics $343,111-134$.

Jolivet, M., Dominguez, S., Charreau, J., Chen, Y., Li, Y.A., and Wang, Q.C., 2010. Mesozoic and Cenozoic tectonic history of the central Chinese Tian Shan: Reactivated tectonic structures and active deformation. Tectonics 29, doi:10.1029/2010TC002712.

Jolivet, M., 2015. Mesozoic tectonic and topographic evolution of Central Asia and Tibet: a preliminary synthesis. Geological Society of London Special Publication (in press).

Ketcham, R.A., Carter, A., Donelick, R.A., Barbarand, J., and Hurford, A.J., 2007. Improved modeling of fission-track annealing in apatite. American Mineralogist 92, 
799-810.

Konopelko, D., Biske, G., Seltmann, R., Eklund, O., and Belyatsky, B., 2007. Hercynian post-collisional A-type granites of the Kokshaal Range, Southern Tien Shan, Kyrgyzstan. Lithos 97, 140-160.

Konopelko, D., Seltmann, R., Biske, G., Lepekhina, E., and Sergeev, S., 2009. Possible source dichotomy of contemporaneous post-collisional barren I-type versus tin-bearing A-type granites, lying on opposite sides of the South Tien Shan suture. Ore Geology Reviews 35, 206-216.

Kröner, A., Wilde, S.A., Li, J.H., and Wang, K.Y., 2005. Age and evolution of a late Archean to Paleoproterozoic upper to lower crustal section in the Wutaishan/Hengshan/Fuping terrain of northern China. Journal of Asian Earth Sciences 24, 577-595.

Li, X.H., Li, W.X., Li, Z.X., Lo, C.H., Wang, J., Ye, M.F., and Yang, Y.H., 2009. Amalgamation between the Yangtze and Cathaysia Blocks in South China: Constraints from SHRIMP U-Pb zircon ages, geochemistry and $\mathrm{Nd}-\mathrm{Hf}$ isotopes of the Shuangxiwu volcanic rocks. Precambrian Research 174, 117-128.

Li, J.H., Cai, Z.Z., Luo, C.S., and Geng Y.H., 2007. The structural transfer at the southern end of Talas-Fergana fault and it regional tectonic response in the Cenozoic. Acta Geologica Sinica 81, 23-31 (in Chinese with English abstract).

Li, Z., and Peng, S.T., 2010. Detrital zircon geochronology and its provenance implications: responses to Jurassic through Neogene basin-range interactions along 
northern margin of the Tarim Basin, Northwest China. Basin Research 22, $126-138$.

Li, Z.X., Bogdanova, S.V., Collins, A.S., Davidson, A., De Waele, B., Ernst, R.E., Fitzsimons, I.C.W., Fuck, R.A., Gladkochub, D.P., Jacobs, J., Karlstrom, K.E., Lu, S., Natapov, L.M., Pease, V., Pisarevsky, S.A., Thrane, K., and Vernikovsky, V., 2008. Assembly, configuration, and break-up history of Rodinia: A synthesis. Precambrian Research 160, 179-210.

Liang, T., Luo, Z.H., Ke, S., Wei, Y., Li, D.D., Huang, J.X., and Huang, F., 2007. SHRIMP ziron dating of the Tuyon volcanoes group, Xinjiang, and its geodynamic implications. Acta Petrologica Sinica 23, 1381-1391 (in Chinese with English abstract).

Liu, D.D., Jolivet, M., Yang, W., Zhang, Z.Y., Cheng, F., Zhu, B., and Guo, Z.J., 2013. Latest Palaeozoic-Early Mesozoic basin-range intersections in South Tian Shan (northwest China) and their tectonic significance: Constraints from detrital zircon U-Pb ages. Tectonophysics 599, 197-213.

Long, X.P., Yuan, C., Sun, M., Zhao, G.C., Xiao, W.J., Wang, Y.J., Yang, Y.H., and Hu,A.Q., 2010. Archean crustal evolution of the northern Tarim craton, NW China: Zircon U-Pb and Hf isotopic constraints. Precambrian Research 180, 272-284.

Luo, J.H., Zhou, X.Y., Qiu, B., Yang, Z.L., Yin, H., and Li, J.X., 2004. Controls of Talas-Fergana Fault on Kashi Sag, Northwestern Tarim Basin. Xinjiang Petroleum Geology 25, 284-287 (in Chinese with English abstract). 
Macaulay, E.A., Sobel, E.R., Mikolaichuk, A., Landgraf, A., Kohn, B., and Stuart, F., 2013. Thermochronologic insight into late Cenozoic deformation in the basement-cored Terskey Range, Kyrgyz Tien Shan. Tectonics 32, 487-500.

Macaulay, E.A., Sobel, E.R., Mikolaichuk, A., Kohn, B., and Stuart, F. A., 2014. Cenozoic deformation and exhumation history of the Central Kyrgyz Tien Shan. Tectonics 33, 135-165.

Miao, J.J., Jia, C.Z., Hou, X.H., Wang, Z.M., Zou, C.N., Tang, L.J., and Song, Y.B., 2007. Structural analysis on Cenozoic fold-and-thrust belt in Kashi area, Western Tarim Basin. Chinese Journal of Geology 42, 740-752 (in Chinese with English abstract).

Mohadjer, S., Bendick, R., Ischuk, A., Kuzikov, S., Kostuk, A., Saydullaev, U., Lodi, S., Kakar, D.M., Wasy, A., Khan, M.A., Molnar, P., Bilham, R., and Zubovich, A.V., 2010. Partitioning of India-Eurasia convergence in the Pamir-Hindu Kush from GPS measurements. Geophysical Research Letters 37, doi:10.1029/2009GL041737.

Molnar, P., and Tapponnier, P., 1975. Cenozoic tectonics of Asia: effects of a continental collision. Science 189, 419-426.

Oskin, M.E., and Burbank, D., 2007. Transient landscape evolution of basement-cored uplifts: Example of the Kyrgyz Range, Tian Shan. Journal of Geophysical Research 112, doi:10.1029/2006JF000563.

Pomazkov, K.D., 1972. Geology of USSR, 25, 280, Nedra, Moscow. 
Ren, R., Han, B.F., Ji, J.Q., Zhang, L., Xu, Z., and Su, L., 2011. U-Pb age of detrital zircons from the Tekes River, Xinjiang, China, and implications for tectonomagmatic evolution of the South Tian Shan Orogen. Gondwana Research $19,460-470$.

Roger, F., Jolivet, M., and Malavieille, J., 2008. Tectonic evolution of the Triassic fold belts of Tibet. Comptes Rendus Geoscience 340, 180-189.

Roger, F., Jolivet, M., and Malavieille, J., 2010. The tectonic evolution of the Songpan-Garzê (North Tibet) and adjacent areas from Proterozoic to Present: A synthesis. Journal of Asian Earth Sciences 39, 254-269.

Rolland, Y., Alexeiev, D.V., Kröner, A., Corsini, M., Loury, C., and Monié, P., 2013. Late Palaeozoic to Mesozoic kinematic history of the Talas-Fergana strike-slip fault (Kyrgyz West Tianshan) as revealed by ${ }^{40} \mathrm{Ar} /{ }^{39} \mathrm{Ar}$ dating of syn-kinematic white mica. Journal of Asian Earth Sciences 67-68, 76-92.

Santosh, M., Sajeev, K., and Li, J.H., 2006. Extreme crustal metamorphism during Columbia supercontinent assembly: Evidence from North China Craton. Gondwana Research 10, 256-266.

Scharer, K.M., Burbank, D.W., Chen, J., Weldon, R.J., Rubin, C., Zhao, R., and Shen, J., 2004. Detachment folding in the Southwestern Tian Shan-Tarim foreland, China: shortening estimates and rates. Journal of Structural Geology 26, 2119-2137.

Seward, D., Spikings, R., Viola, G., Kounov, A., Ruiz, G., and Naeser, N., 2000. Etch times and operator variation for spontaneous track length measurement in apatites: 
an inta-laboratory check. OnTrack 10, 16-21.

Shu, L.S., Deng, X.L., Zhu, W.B., Ma, D.S., and Xiao, W.J., 2011. Precambrian tectonic evolution of the Tarim Block, NW China: New geochronological insights from the Quruqtagh domain. Journal of Asian Earth Sciences 42, 774-790.

Sircombe, K.N., 1999. Tracing provenance through the isotope ages of littoral and sedimentary detrital zircon, eastern Australia. Sedimentary Geology 124, 47-67.

Sobel, E.R., and Dumitru, T.A., 1997. Thrusting and exhumation around the margins of the western Tarim basin during the India-Asia collision. Journal of Geophysical Research 102, 5043-5063.

Sobel, E.R., 1999. Basin analysis of the Jurassic-Lower Cretaceous southwest Tarim basin, northwest China. Geological Society of America Bulletin 111, 709-724.

Sobel, E.R., and Arnaud, N., 2000. Cretaceous-Paleogene basaltic rocks of the Tuyon basin, NW Chia and the Kyrgyz Tian Shan: the trace of a small plume. Lithos 50, $191-215$.

Sobel, E.R., Chen, J., and Heermance, R.V., 2006a. Late Oligocene-Early Miocene initiation of shortening in the Southwestern Chinese Tian Shan: Implications for Neogene shortening rate variations. Earth and Planetary Science Letters 247, $70-81$.

Sobel, E.R., Oskin, M., Burbank, D., and Mikolaichuk, A., 2006b. Exhumation of basement-cored uplifts: Example of the Kyrgyz Range quantified with apatite fission track thermochronology. Tectonics 25, doi:10.1029/2005TC001809. 
Sobel, E.R., and Seward, D., 2010. Influence of etching conditions on apatite fission-track etch pit diameter. Chemical Geology 271, 59-69.

Sun, J.M., Zhu, R.X., and An, Z.S., 2005. Tectonic uplift in the northern Tibetan Plateau since 13.7 Ma ago inferred from molasse deposits along the Altyn Tagh Fault. Earth and Planetary Science Letters 235, 641-653.

Sun, J.M., Li, Y., Zhang, Z.Q., and Fu, B.H., 2009a. Magnetostratigraphic data on Neogene growth folding in the foreland basin of the southern Tianshan Mountains. Geology 37, 1051-1054.

Sun, J.M., and Zhang, Z.Q., 2009b. Syntectonic growth strata and implications for late Cenozoic tectonic uplift in the northern Tian Shan, China. Tectonophysics 463, $60-68$.

Sun, J.M., and Jiang, M.S., 2013. Eocene seawater retreat from the southwest Tarim and implication for early Cenozoic tectonic evolution in the Pamir Plateau. Tectonophysics 588, 27-38.

Tagami, T., 1987. Determination of zeta calibration constant for fission track dating. Nuclear Tracks and Radiation Measurements 13, 127-130.

Turchinskiy, V.P., 1970. Geological map of the USSR of 1:200 000 scales, Northern Tien Shan series, Sheet K-43-XVIII. Russian Geological Research Institute, Nedra, Moscow.

Verzilin, N.N., 1968. On the problem of the Talas-Ferghana strike-slip fault, in Ognev, V. N., ed.. Problems of regional geology: Leningrad, Leiningrad University 67-70 
(in Russian).

Trifonov, V., Artyushkov, E., Dodonov, A., Bachmanov, D., Mikolaichuk, A., and Vishnyakov, F., 2008. Pliocene-quaternary orogeny in the Central Tien Shan. Russian Geology and Geophysics 49, 98-112.

Wang, E., Wan, J.L., and Liu, J.Q., 2003. Late Cenozoic geological evolution of the foreland basin bordering the West Kunlun range in Pulu area: Constraints on timing of uplift of northern margin of the Tibetan Plateau. Journal of Geophysical Research 108, doi:10.1029/2002JB001877

Wang, Y.B., Wang, Y., Liu, X., Fu, D.R., Xiao, X.C., and Qi, L.S., 2000. Geochemical characteristics and genesis of Late Cretaceous to Paleoene Basalts in Tuyon Basin, South Tianshan Mountain. Acta Petrologica et Mineralogica 19, 131-139 (in Chinese with English abstract).

Wilde, S.A., Zhao, G.C., and Sun, M., 2002. Development of the North China Craton During the Late Archaean and its Final Amalgamation at $1.8 \mathrm{Ga}$ : Some Speculations on its Position Within a Global Palaeoproterozoic Supercontinent. Gondwana Research 5, 85-94.

Woelfler, A., Rabitsch, R., and Kurz, W., 2008. Fission track dating of fault rocks: Evidence from chemical composition, track length reduction and single grain ages of apatites. European Geosciences Union, Geophysical Research Abstract 10.

Wu, L., Xiao, A.C., Yang, S.F., Wang, L.Q., Mao, L.G., Wang, L., Dong, Y.P., and Xu, B., 2012. Two-stage evolution of the Altyn Tagh Fault during the Cenozoic: new 
insight from provenance analysis of a geological section in NW Qaidam Basin, NW China. Terra Nova 24, 387-395.

Yang, W., Jolivet, M., Dupont-Nivet, G., and Guo, Z.J., 2014. Mesozoic-Cenozoic tectonic evolution of southwestern Tian Shan: Evidence from detrital zircon U/Pb and apatite fission track ages of the Ulugqat area, Northwest China. Gondwana Research 26, 986-1008.

Yin, A., Nie, S., Craig, P., Harrison, T.M., Ryerson F.J., Qian X.L., and Yang G., 1998. Late Cenozoic tectonic evolution of the southern Chinese Tian Shan. Tectonics 17, $1-27$.

Yin, A., Rumelhart, P.E., Butler, R., Cowgill, E., Harrison, T.M., Foster, D.A., Ingersoll, R.V.,Q Zhang, Q., Zhou, X.Q., Wang, X.F., Hanson, A., and Raza, A., 2002. Tectonic history of the Altyn Tagh fault system in northern Tibet inferred from Cenozoic sedimentation. Geological Society of America Bulletin 114: $1257-1295$.

Yin, A., 2010. Cenozoic tectonic evolution of Asia: A preliminary synthesis. Tectonophysics 488, 293-325.

Zhang, C.L., Li, Z.X., Li, X.H., Yu, H.F., and Ye, H.M., 2007a. An early Paleoproterozoic high-K intrusive complex in southwestern Tarim Block, NW China: Age, geochemistry, and tectonic implications. Gondwana Research 12, 101-112.

Zhang, C.L., Li, X.H., Li, Z.X., Lu, S.N., Ye, H.M., and Li, H.M., 2007 b. 
Neoproterozoic ultramafic-mafic-carbonatite complex and granitoids in Quruqtagh of northeastern Tarim Block, western China: Geochronology, geochemistry and tectonic implications. Precambrian Research 152, 149-169.

Zhang, H.N., 1989. Geochemical characteristics and resource prediction of Meso-Cenozoic source roks in Tarim, in Petroleum Resource-Prospects and Evaluations, Selected Paper on Petroleum and Natural Gas Geology. Geology Publication, Beijing, 53-76.

Zhang, Z.Y., Zhu, W.B., Shu, L.S., Wan, J.L., Yang, W., Su, J.B., and Zheng, B.H., 2009. Apatite fission track thermochronology of the Precambrian Aksu blueschist, NW China: Implications for thermo-tectonic evolution of the north Tarim basement. Gondwana Research 16, 182-188.

Zhang, Z.Y., Zhu, W.B., Shu, L.S., Wang, J.L., Yang, W., Zheng, B.H., and Su, J.B., 2011. Multi-stage exhumation of the NE Tarim Precambrian bedrock NW China: constrais from apatite fission track thermochronology in the Kuluketage area. Terra Nova 23, 324-332.

Zhao, G.C., Cawood, P.A., Wilde, S.A., and Sun, M., 2002. Review of global 2.1-1.8 Ga orogens: implications for a pre-Rodinia supercontinent. Earth Science Reviews $59,125-162$.

Zubovich, A.V., Wang, X.Q., Scherba, Y.G., Schelochkov, G.G., Reilinger, R., Reigber, C., Mosienko, O.I., Molnar, P., Michajljow, W., Makarov, V.I., Li, J., Kuzikov, S.I., Herring, T.A., Hamburger, M.W., Hager, B.H., Dang, Y.M., Bragin, V.D., and 
Beisenbaev, R.T., 2010. GPS velocity field for the Tien Shan and surrounding regions. Tectonics 29, doi:10.1029/2010TC002772. 


\section{Figure captions}

Fig. 1 Simplified active tectonic map of the SW Tian Shan and adjacent regions mapped from the Landsat TM imagery showing major Cenozoic faults (modified from Fu et al., 2011, and Jolivet et al., 2010). KKTB: Kuqa-Korla thrust belt; KPT: Kalpingtage thrust; WKB: West Kunlun thrust belt; TFF: Talas-Fergana fault; KYTF: Kashi-Yecheng Transfer system, KXF: Kangxiwa Fault. Location of Fig. 2a is marked by the black box.

Fig. 2 (a) The topography and tectonic map of the SW Chinese Tian Shan.; (b) the 30 km wide DEM swath profile across the Atbashi Range, Aksai Basin, Kokshaal Range and the Atushi Basin.

Fig. 3 (a) False colour ASTER composite image of 2/1 (R), 3 (G) and 4/8 (B); (b) geological interpretative map displaying the tectono-geomorphological features and AFT samples. The cross-section A-A' is shown in Fig. 4.

Fig. 4(a) Cross-section of the study area along A-A' of fig. 3 (b), and AFT samples from this study; (b) a detailed map of the growth strata on the south flank of the Keketamu anticline and clast compositions investigation of the Xiyu Fm.. 
Fig.5 Summary of AFT and AHe data across the Western Tian Shan Range (Bullen et al., 2001; Dumitru et atl., 2001; Sobel et al., 2006a, 2006b; Zhang et al., 2009; Glorie et al., 2010, 2011; De Grave et al., 2011, 2012; Chang et al., 2012: Macaulay et al., 2014)

Fig. 6 Thermal history modelling and confined track length distribution of TK-09 and TK-10 with the multikinetic annealing model of Ketcham et al, 2007, the thermal history modelling was carried out using the QTQt program (Gallagher et al., 2009; Gallagher, 2012).

Fig. 7 Dpar analysis of apatite single grains of detrital samples

Fig. 8 Radial plots showing age components of the non-resetted detrital apatite samples. Plots were made using the Trackkey software (Dunkl, 2002). Age components were modelled and calculated using the Bayesmix software (Jasra et al., 2005; Gallagher et al., 2009).

Fig. 9 Simplified geological map of the SW Chinese Tian Shan Range and surrounding regions (modified after Gao et al., 2009), the red dots are basement U-Pb ages dated Konopelko et al (2007) and Glorie et al (2011) and Ar-Ar ages in Sobel et 
al., 2000.

Fig. 10 Concordia plots for detrital zircons of samples (with an error of 1 sigma) collected from Cenozoic strata of Atushi Basin, SW Chinese Tian Shan. Ages with disconcordance degree $>10 \%$ were excluded.

Fig. 11 Relative probability plots histograms of $\mathrm{U}-\mathrm{Pb}$ ages of detrital zircons from Cenozoic sandstone samples in the Atushi Basin.

Fig. 12 Lag time plot for the Cenozoic sedimentary rocks in the Atushi Basin. Depositional ages are based on Heermance et al., 2007 and Chen et al., 2002. The black dots are our data and the yellow dots are from Sobel et al., 2006a.

Fig. 13 3D cartoon schematically showing the tectono-geomorphological evolution of the SW Chinese Tian Shan. The underground structures are rectified from Fu et al., 2010; Hou et al., 2012 and Gao et al., 2013. (ABT: Atushi Basin Thrust; MF: Maidan fault, MZF: Muziduke fault, STSs: South Tian Shan suture and TFF: Talas-Fergana fault) 


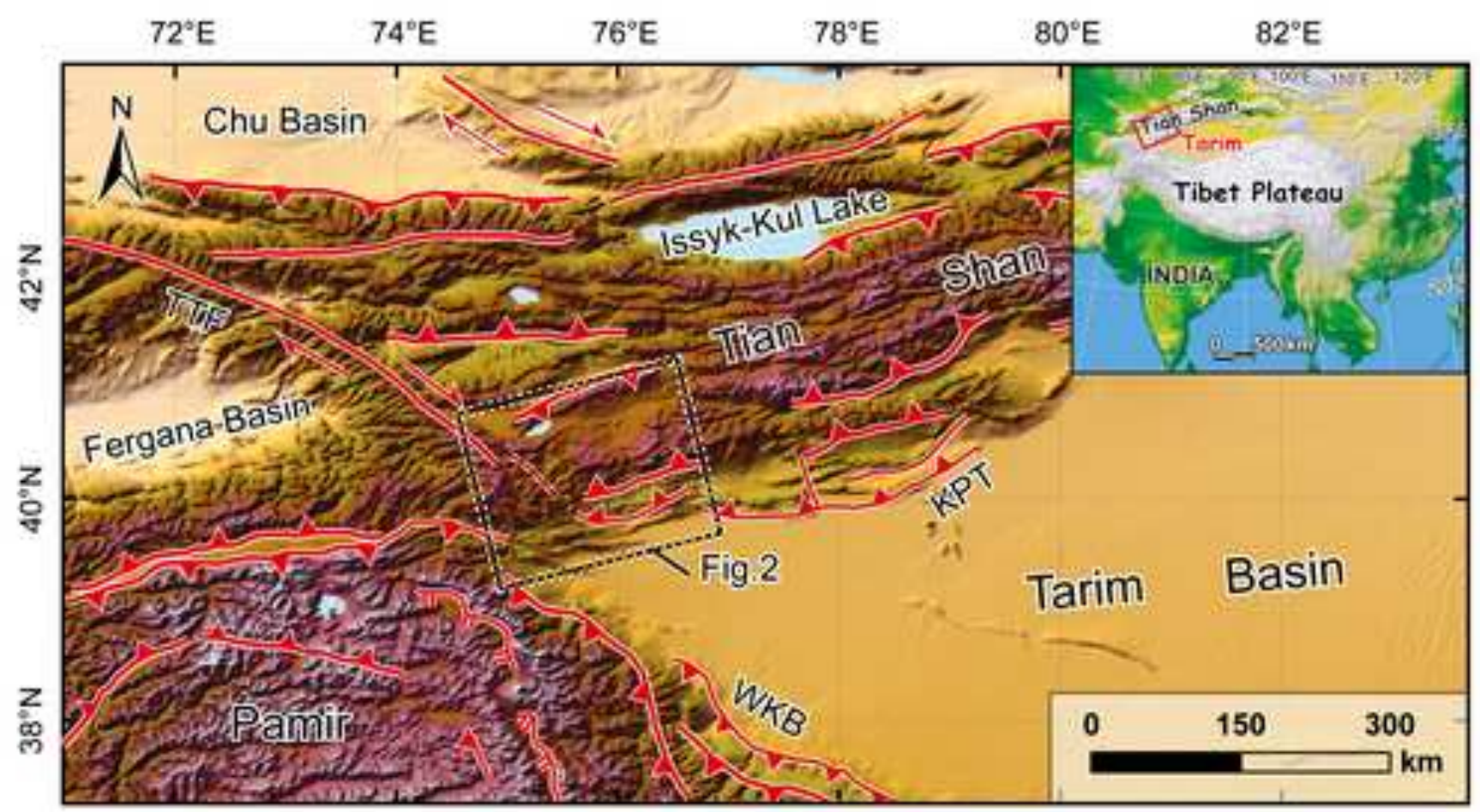




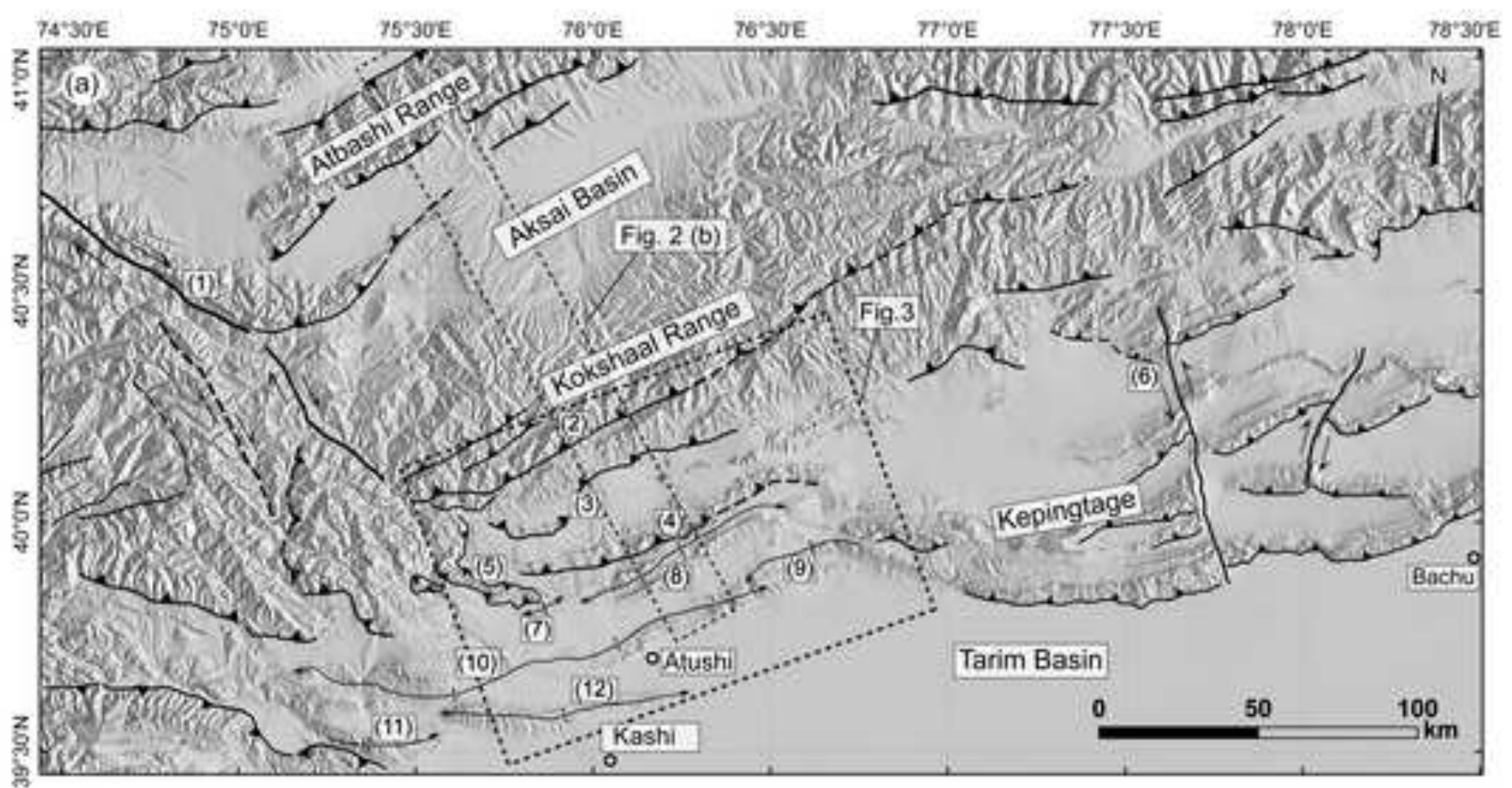
thrust faut
(1) Talas-Forgana Faus
(5) Wenguer Klippe
(9) Mutule Antictine
strike-slip fautt
(2) Maidan Faut
(6) Pigiang Faut
(10) Anushi-Talanghe Anticline
A. anticline
(3) Muziduke Fault
(7) Tashipishake Antecline
(11) Mingysole Anticline
(4) Atushi Basin Thrust (ABT)
(8) Keketamu Anticline
(12) Kashi Anticline

(b)

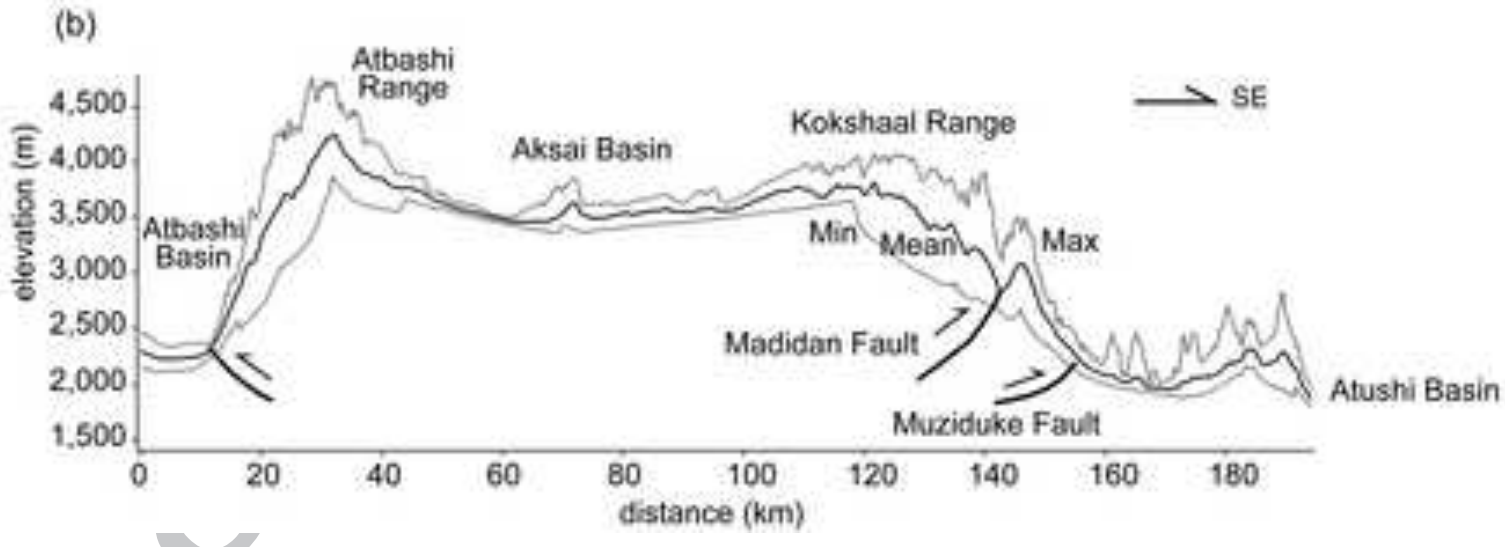




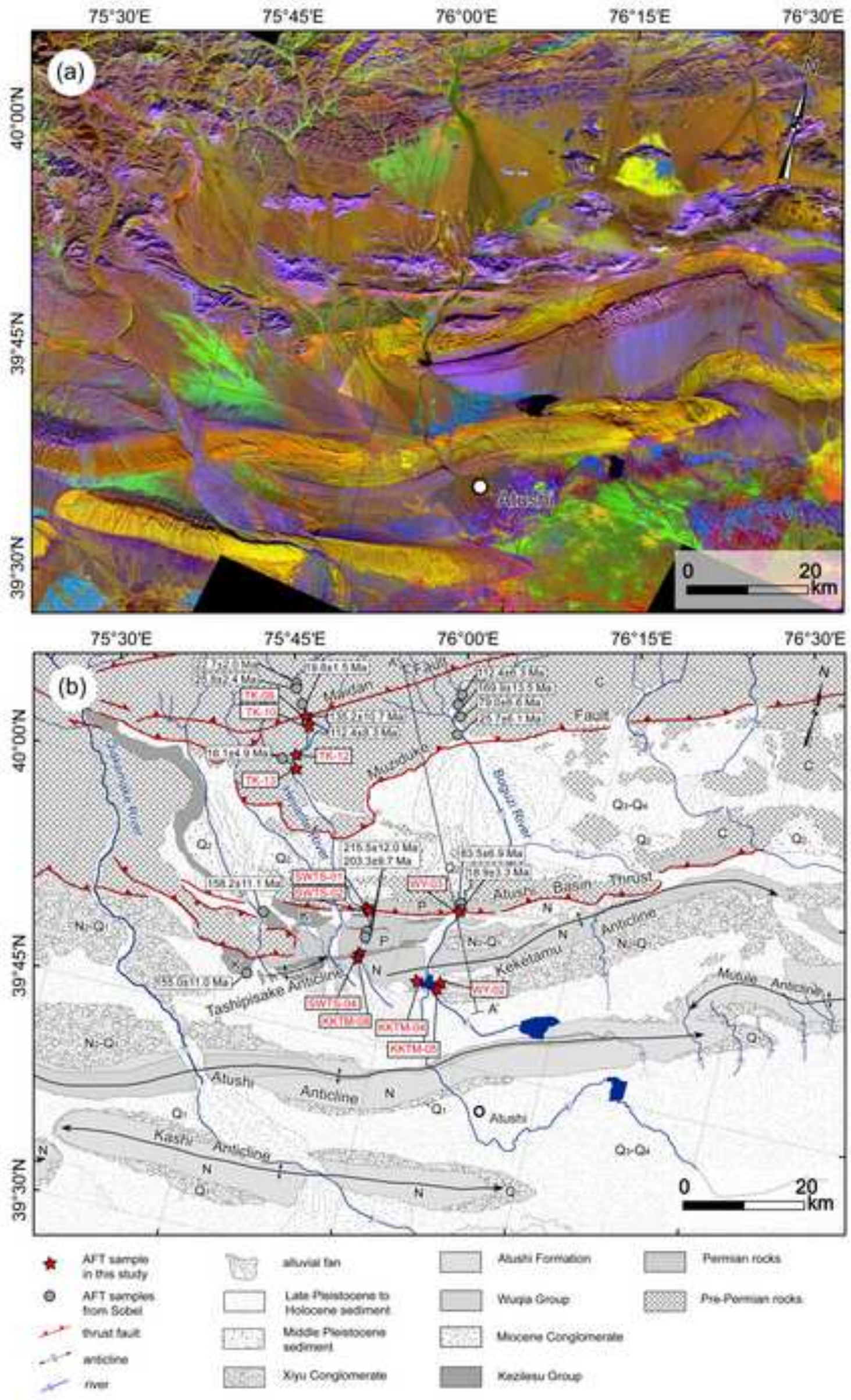




\section{(a)}

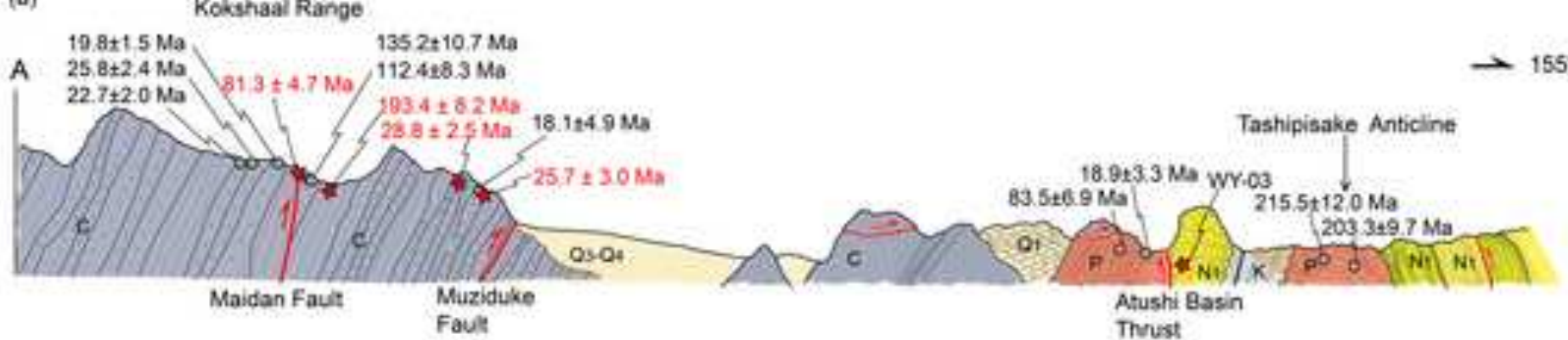

$135.2+10.7 \mathrm{Ma}$

A $25.8 \pm 2.4 \mathrm{Ma}$ a $3+4.7 \mathrm{Ma} / 112448.3 \mathrm{Ma}$ Threst

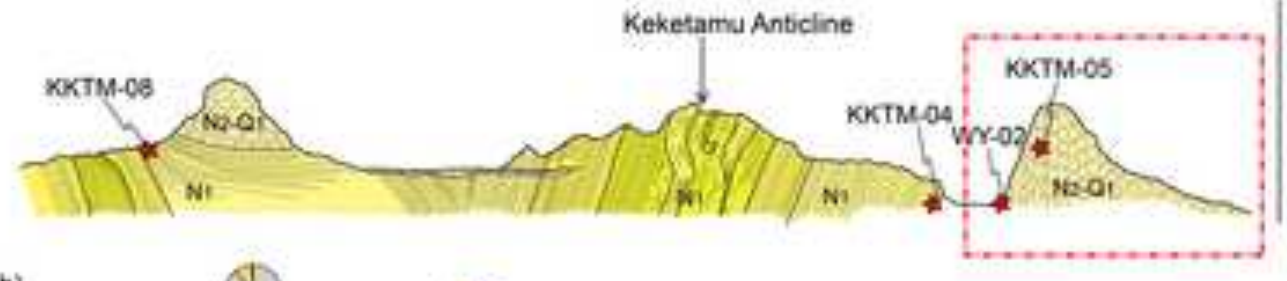

$2 \mathrm{~km}$

(b)

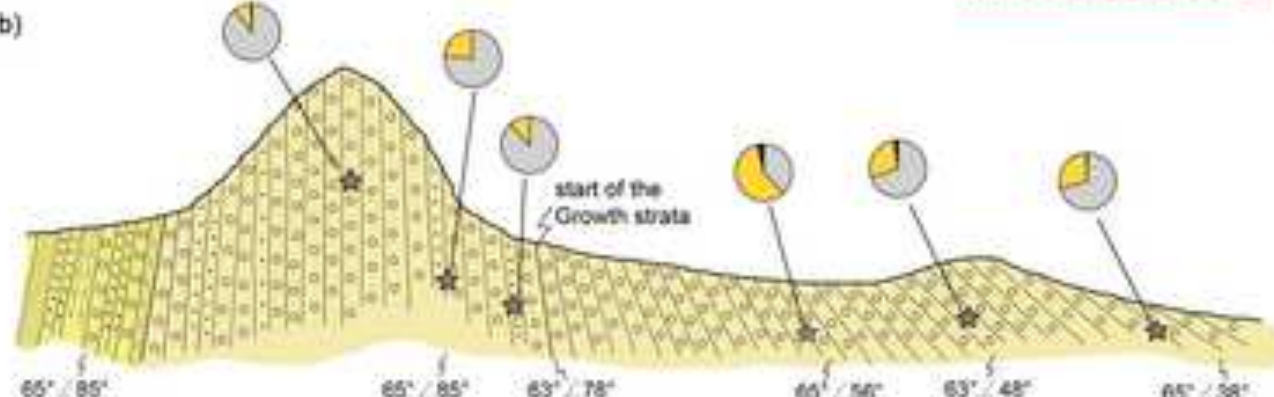

66. 05

es: 28 '

es. 78

$10^{2} \mathrm{cser}$

$65 \div 38$ :

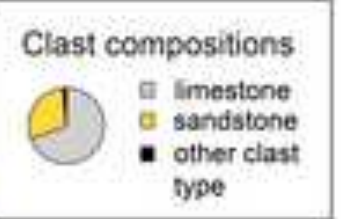

* AFT sample

- AFT sample from Soble et al , 2006 Thrust fautt

\section{Alluvial tan}

Pleistocene congiomerate

Xyu Formation

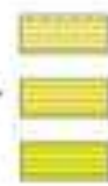

\section{Pakabulake} Formation

Anjuan Formation

Kezluoyi Formation
Fincene conglom: erate

Miocene sandstone

Permian Sediment $>155^{\circ}$ 
$73^{\circ} \mathrm{E}$

$74^{\circ} \mathrm{E}$

$75^{\circ} \mathrm{E}$

$76^{*} \mathrm{E}$

$77^{\circ} \mathrm{E}$

$78^{\circ} \mathrm{E}$

$79^{\circ} \mathrm{E}$

$80^{\circ} \mathrm{E}$

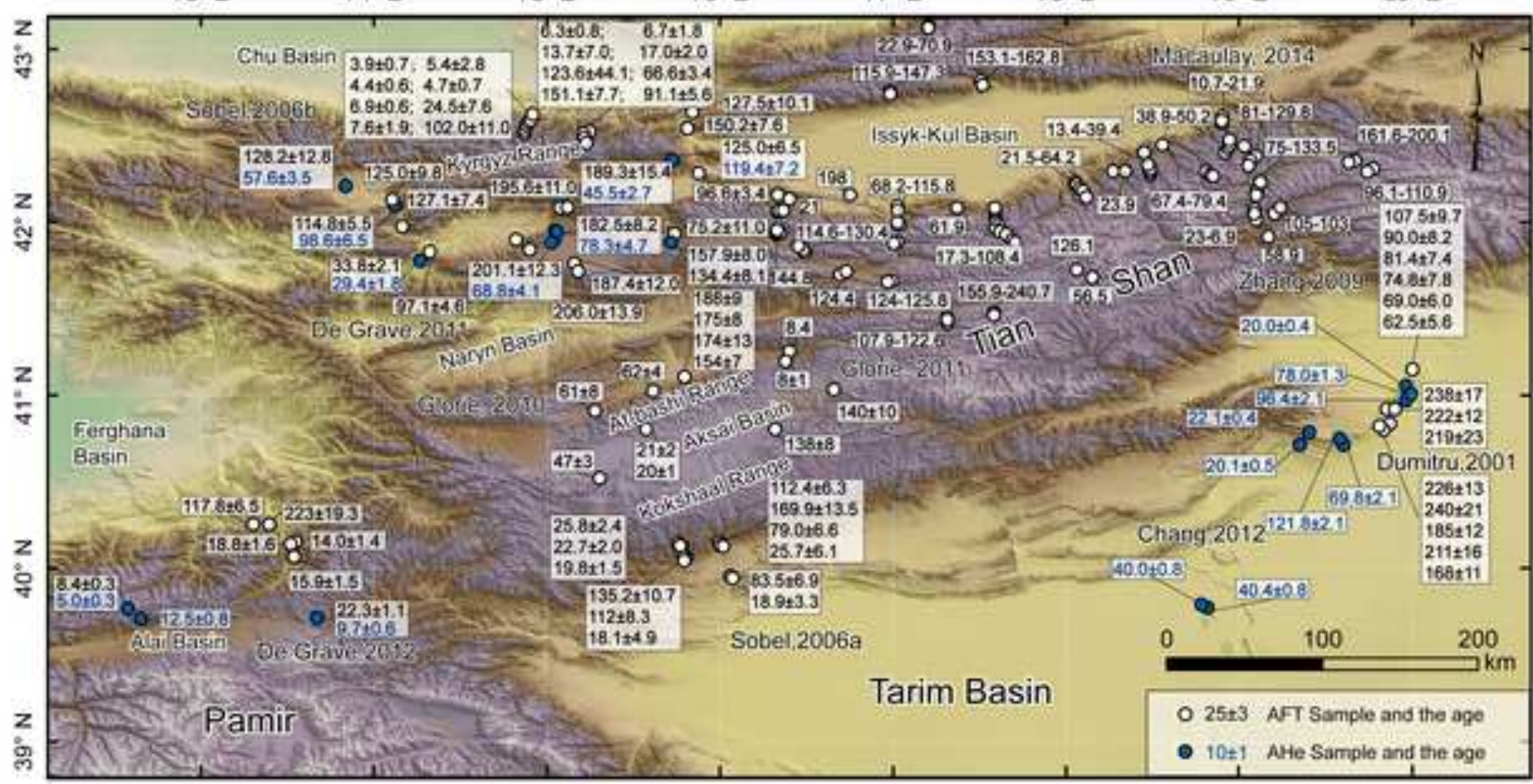



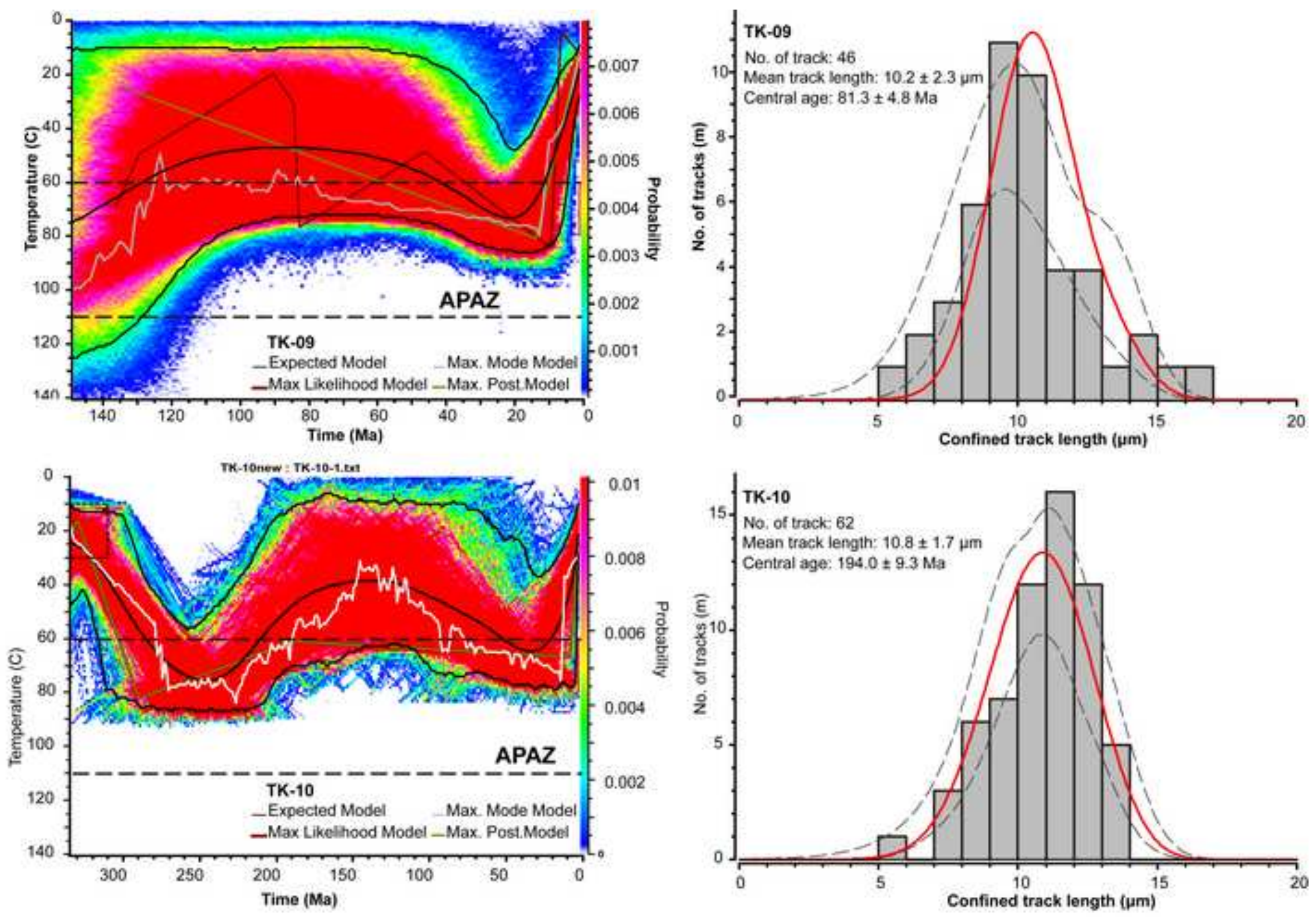


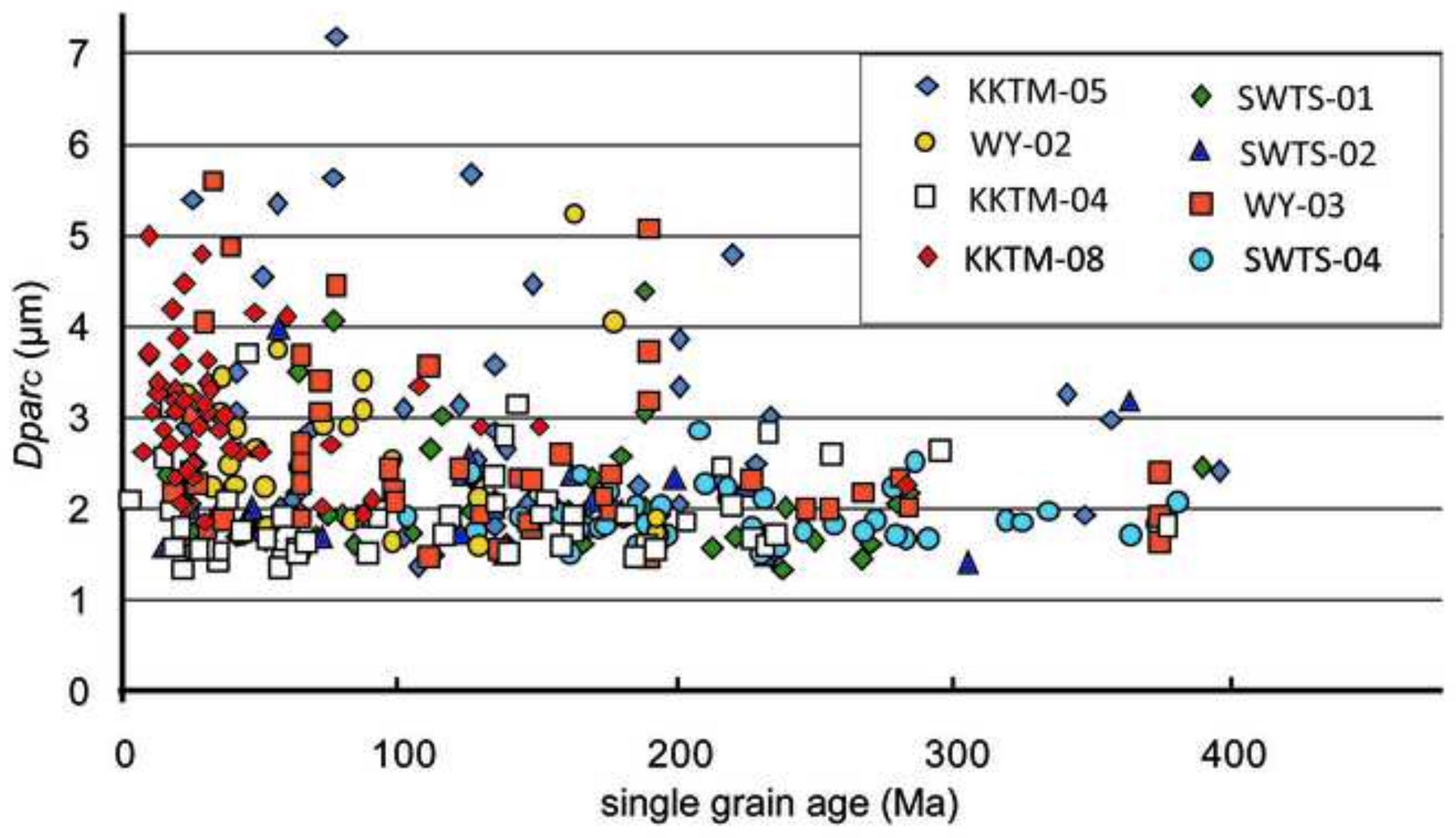



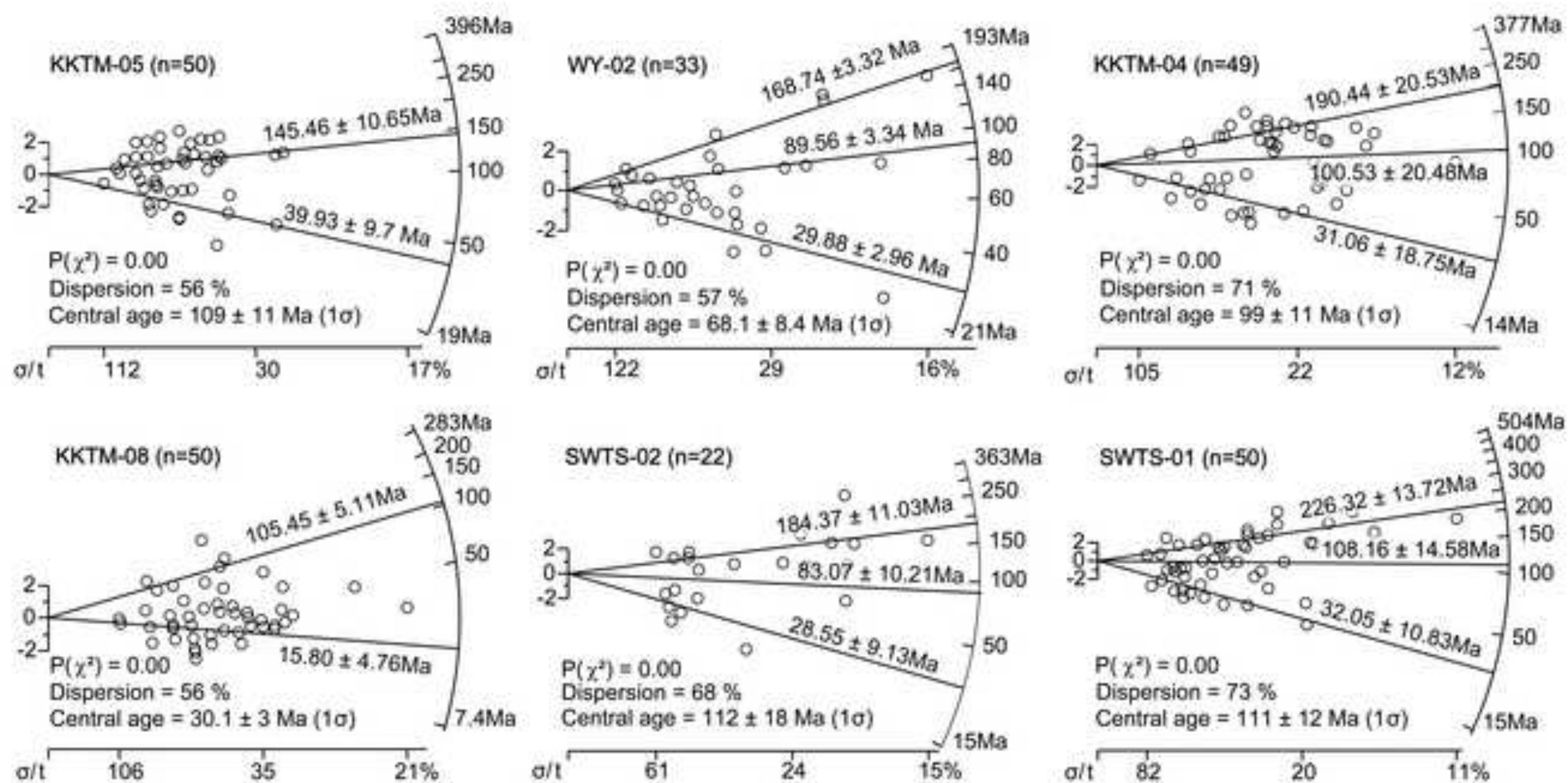

$\begin{array}{llll}\text { ort } & 106 & 35 & 21 \%\end{array}$

a/

61

o/t 82

$11 \%$
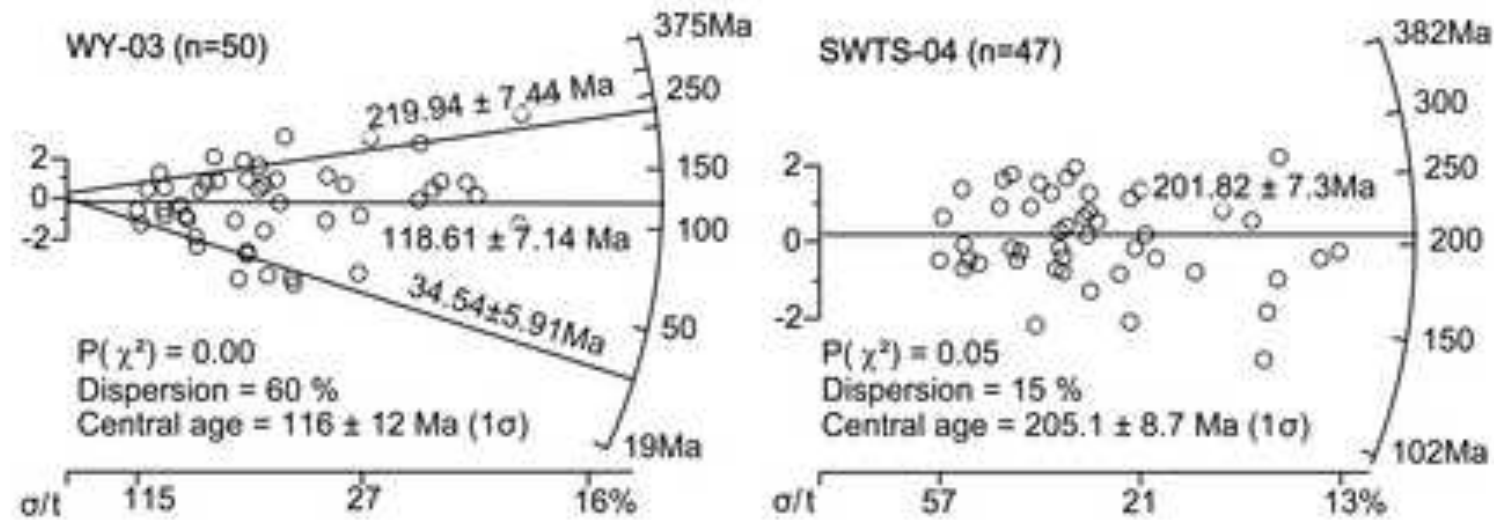

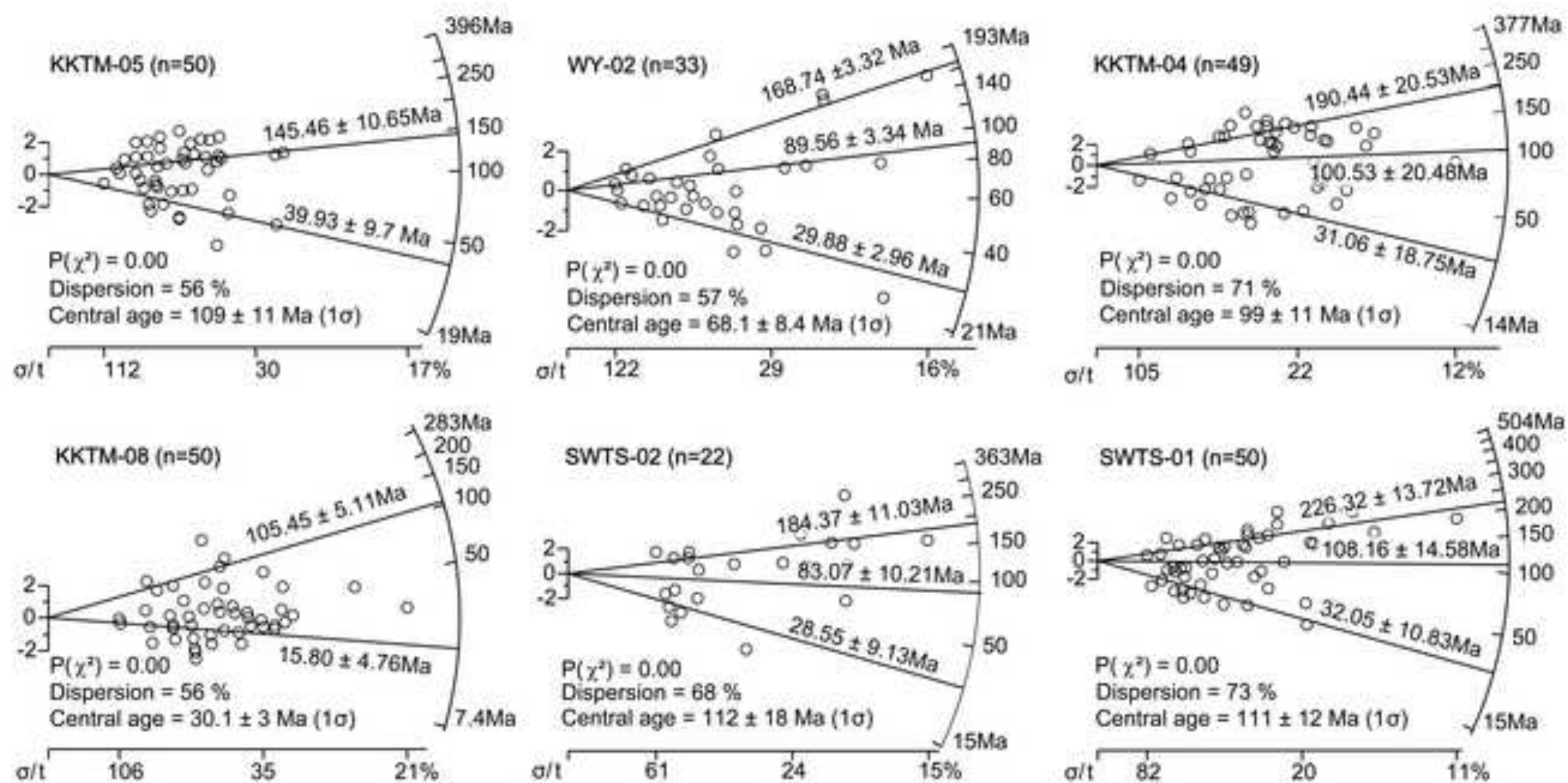

$\begin{array}{llll}\text { ort } & 106 & 35 & 21 \%\end{array}$

a/

61

o/t 82

$11 \%$
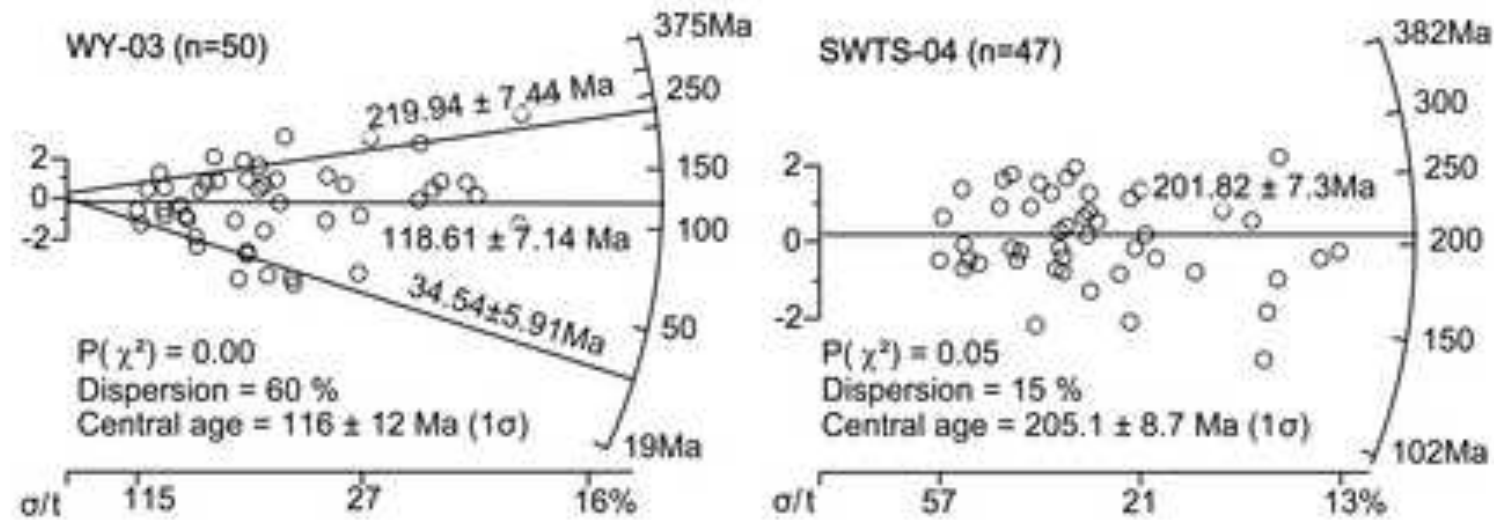

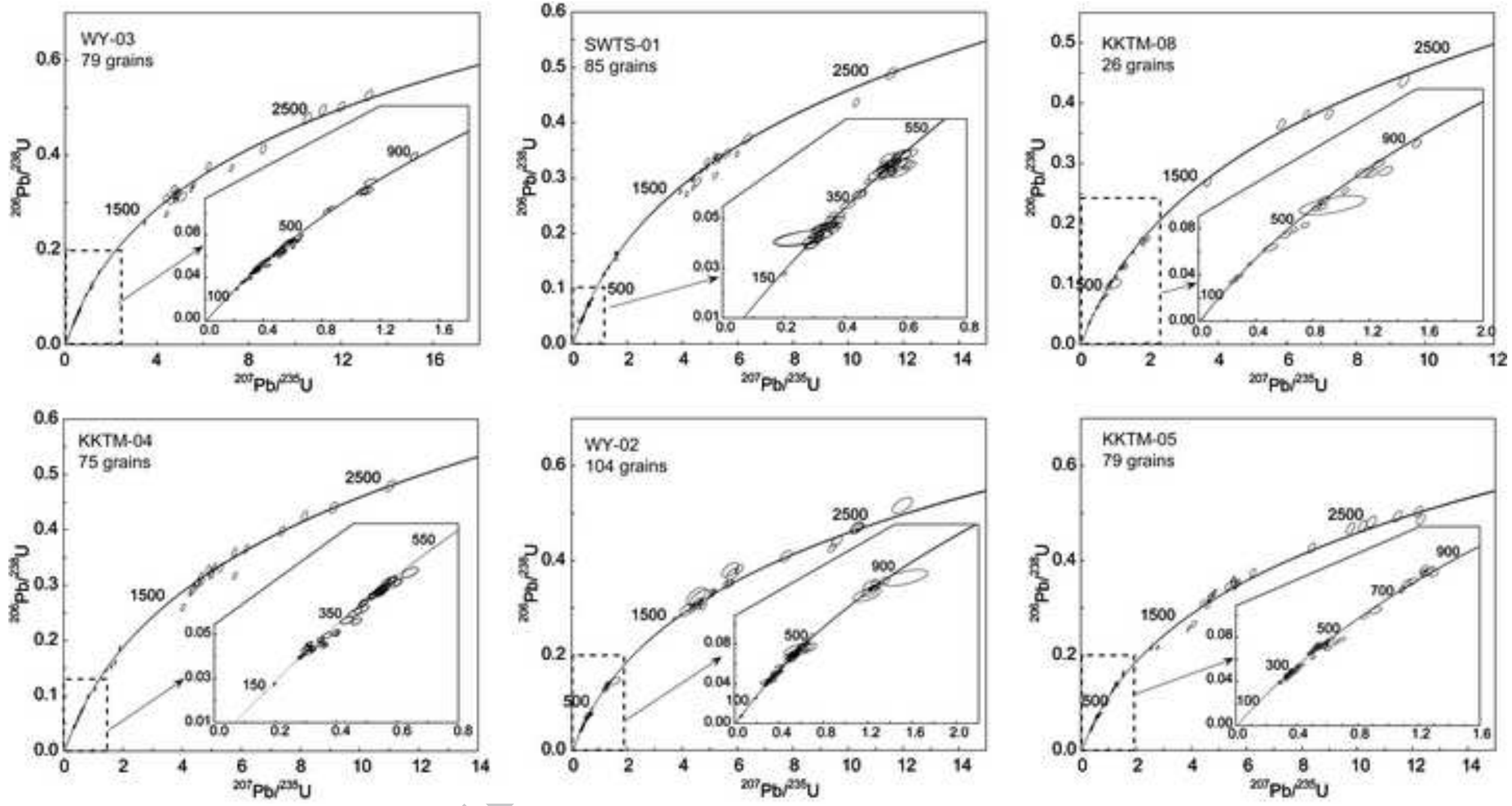
ACCEPTED MANUSCRIPT
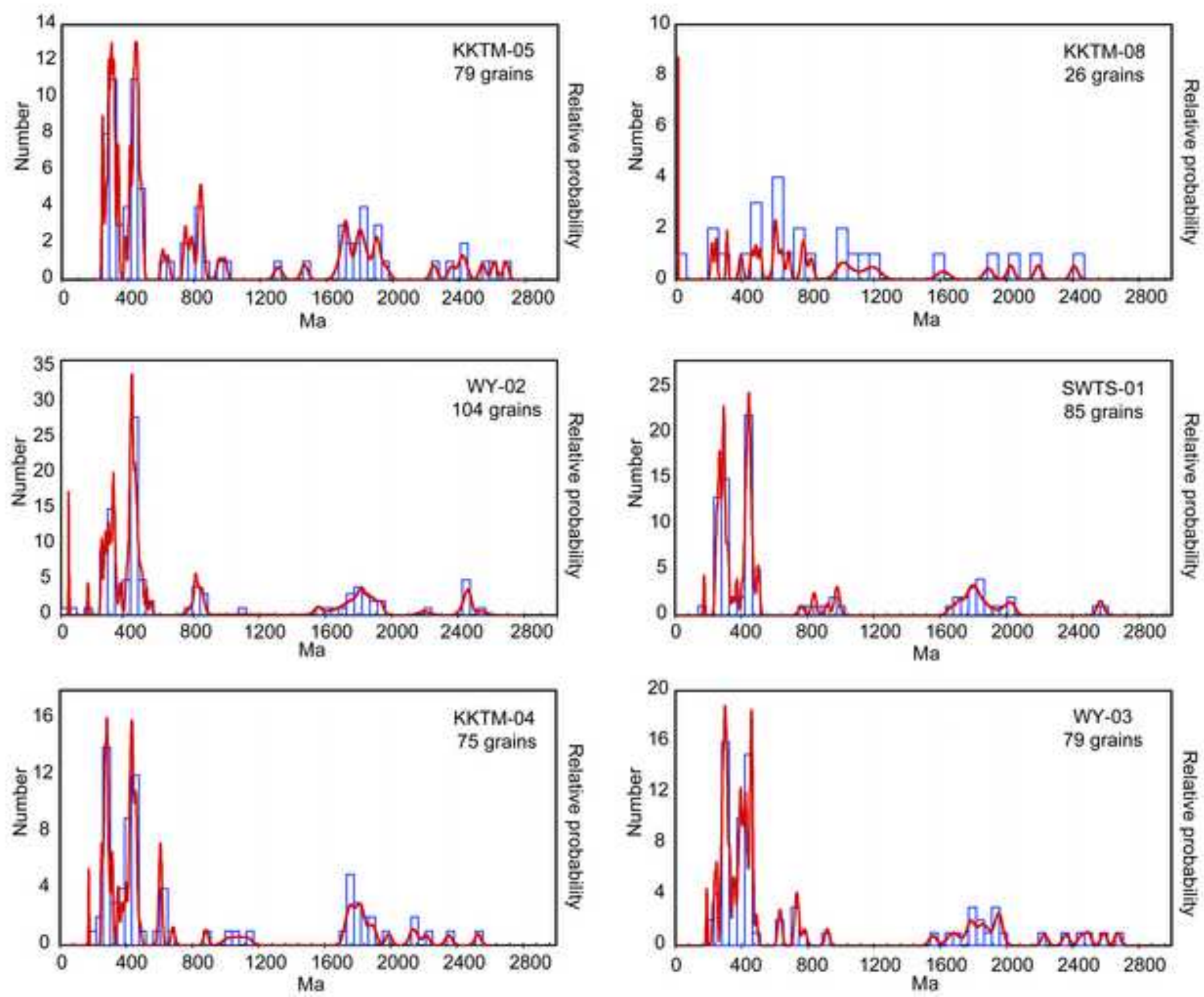


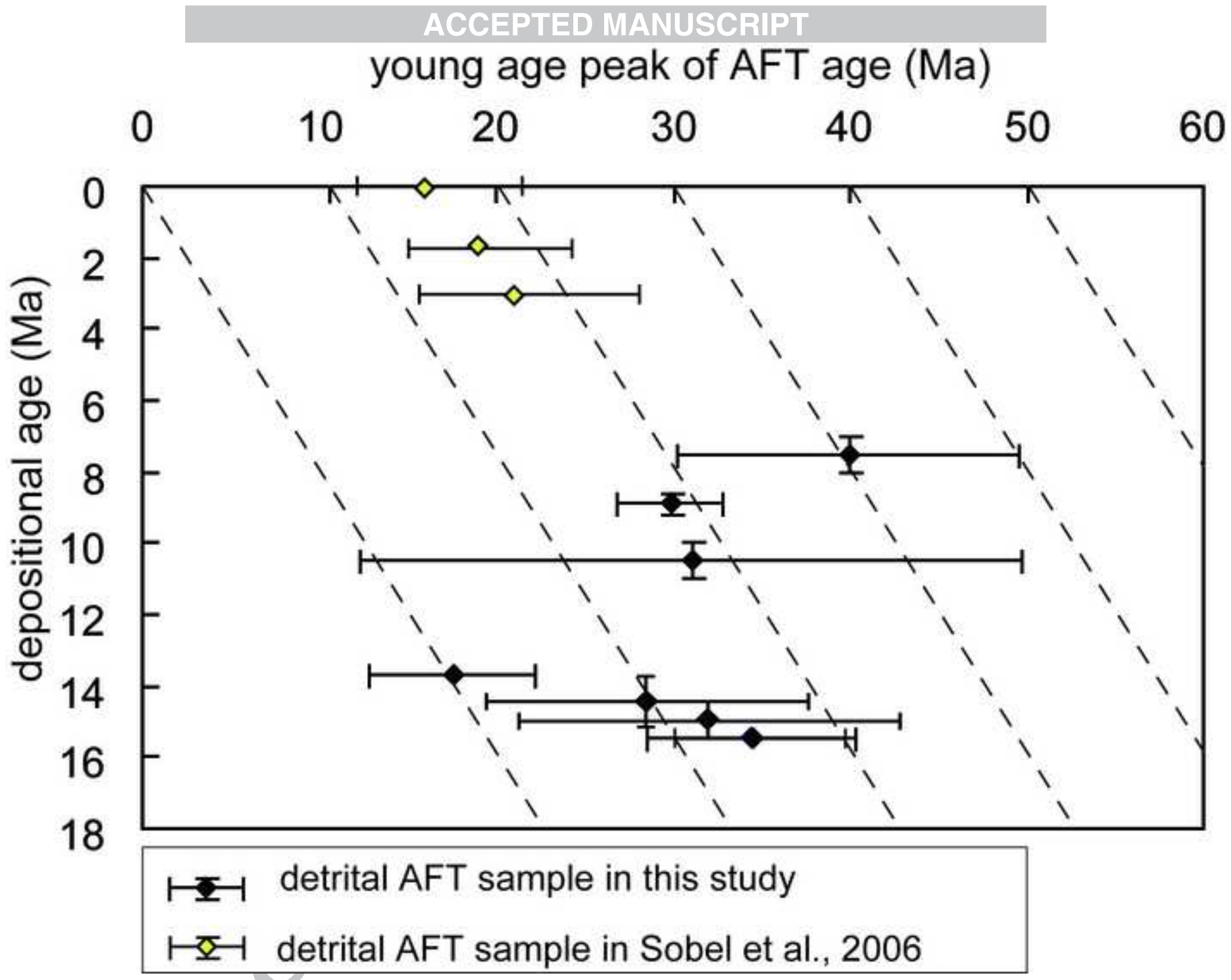




\section{ACCEPTED MANUSCRIPT}
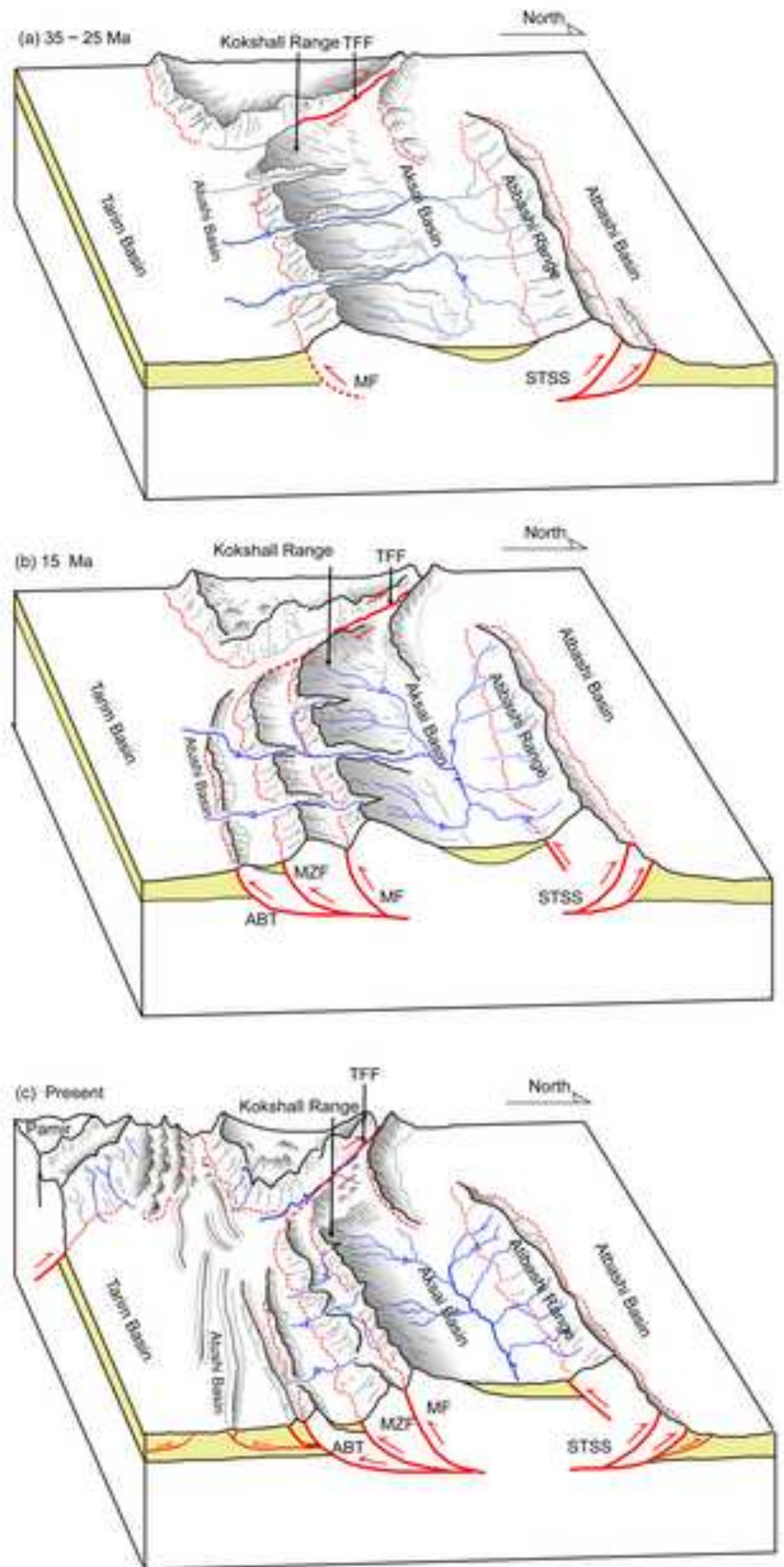
Table. 1 Geographic positions, altitudes, and lithology of the samples; AFT: apatite fission track dating, ZUPb: detrital zircon U-Pb dating.

\begin{tabular}{|c|c|c|c|c|c|}
\hline Sample & Latitude & Longitude & Altitude & Lithology & Method \\
\hline TK-09 & $40^{\circ} 05^{\prime} 57.18^{\prime \prime}$ & $75^{\circ} 47^{\prime} 07.29^{\prime \prime} \mathrm{E}$ & $2508 \mathrm{~m}$ & Carboniferous quartz sandstone & AFT \\
\hline TK-10 & $40^{\circ} 04^{\prime} 52.10^{\prime \prime}$ & $75^{\circ} 47^{\prime} 31.47^{\prime \prime} \mathrm{E}$ & $2471 \mathrm{~m}$ & Carboniferous quartz sandstone & AFT \\
\hline TK-12 & $40^{\circ} 03^{\prime} 27.80^{\prime \prime}$ & $75^{\circ} 47^{\prime} 36.57^{\prime \prime} \mathrm{E}$ & $2406 \mathrm{~m}$ & Carboniferous quartz sandstone & AFT \\
\hline TK-13 & $40^{\circ} 02^{\prime} 38.40^{\prime \prime}$ & $75^{\circ} 47^{\prime} 06.00^{\prime \prime} \mathrm{E}$ & $2374 \mathrm{~m}$ & Carboniferous quar & AFT \\
\hline SWTS-01 & $39^{\circ} 54^{\prime} 07.66^{\prime \prime}$ & $75^{\circ} 56^{\prime} 21.69^{\prime \prime} \mathrm{E}$ & $1921 \mathrm{~m}$ & Miocene sands & AFT,ZUPb \\
\hline SWTS-02 & $39^{\circ} 54^{\prime} 06.37^{\prime \prime}$ & $75^{\circ} 56^{\prime} 22.07^{\prime \prime} \mathrm{E}$ & $1906 \mathrm{~m}$ & Miocene & AFT \\
\hline SWTS-04 & $39^{\circ} 50^{\prime} 54.34^{\prime \prime} \mathrm{N}$ & $75^{\circ} 56^{\prime} 37.77^{\prime \prime} \mathrm{E}$ & $1771 \mathrm{~m}$ & Cretaceous sandstone & AFT \\
\hline WY-02 & $39^{\circ} 50^{\prime} 14.46^{\prime \prime} \mathrm{N}$ & $76^{\circ} 04^{\prime} 13.97^{\prime \prime} \mathrm{E}$ & $1598 \mathrm{~m}$ & Miocene sandstone & AFT,ZUPb \\
\hline WY-03 & $39^{\circ} 55^{\prime} 19.22^{\prime \prime} \mathrm{N}$ & $76^{\circ} 04^{\prime 2} 29.67^{\prime \prime} \mathrm{E}$ & $1720 \mathrm{~m}$ & Miocene sandstone & AFT,ZUPb \\
\hline KKTM-04 & $39^{\circ} 49^{\prime} 55.62^{\prime \prime} \mathrm{N}$ & $76^{\circ} 01^{\prime} 40.53^{\prime \prime} \mathrm{E}$ & $1578 \mathrm{~m}$ & Sandstone (Pakabulake Fm.) & AFT,ZUPb \\
\hline KKTM-05 & $39^{\circ} 49^{\prime} 48.72^{\prime \prime} \mathrm{N}$ & $76^{\circ} 03^{\prime} 37.81^{\prime \prime} \mathrm{E}$ & $1581 \mathrm{~m}$ & Sandstone (Xiyu Fm.) & AFT,ZUPb \\
\hline KKTM-08 & $39^{\circ} 50^{\prime} 36.63^{\prime \prime} \mathrm{N}$ & $75^{\circ} 56^{\prime} 48.16^{\prime \prime} \mathrm{E}$ & $1785 \mathrm{~m}$ & Sandstone (Pakabulake Fm.) & AFT,ZUPb \\
\hline
\end{tabular}

Table. 2 apatite fission track data

\begin{tabular}{|c|c|c|c|c|c|c|c|c|c|c|c|c|c|}
\hline Sample & $\begin{array}{l}\text { No. G } \\
\text { grain }\end{array}$ & $\begin{array}{c}\rho_{\mathrm{d}} \times 10^{5} \\
\left(\mathrm{~cm}^{-2}\right)\end{array}$ & $\begin{array}{l}\rho_{\mathrm{s}} \times 10^{5} \\
\left(\mathrm{~cm}^{-2}\right)\end{array}$ & $\begin{array}{l}\rho_{\mathrm{i}} \times 10^{5} \\
\left(\mathrm{~cm}^{-2}\right)\end{array}$ & $\begin{array}{l}\mathrm{U} \\
\text { (ppm) }\end{array}$ & $\begin{array}{l}\mathrm{P}\left(\chi^{2}\right) \\
(\%)\end{array}$ & $\begin{array}{l}\text { Age } \\
\text { (Ma) }\end{array}$ & $\begin{array}{l}\text { error } \\
( \pm 1 \sigma \\
\end{array}$ & $\begin{array}{l}\operatorname{Dpar}_{M} \\
(\mu \mathrm{m})\end{array}$ & $\operatorname{Dpar}_{C}$ & $\begin{array}{l}\text { Length } \\
(\mu \mathrm{m})\end{array}$ & $\begin{array}{l}\text { Stdev. } \\
(\mu \mathrm{m})\end{array}$ & $\begin{array}{l}\text { No. L } \\
\text { length }\end{array}$ \\
\hline \multirow[t]{2}{*}{ TK-09 } & 24 & 14.39 & 3.41 & 10.22 & 8.95 & 62.57 & 81.3 & 4.7 & 1.27 & 1.51 & 10.2 & 2.3 & 46 \\
\hline & & & (433) & (1298) & & & & & & & & & \\
\hline \multirow[t]{2}{*}{ TK-10 } & 20 & 14.00 & 19.25 & 23.4 & 20.30 & 24.06 & 193.4 & 8.2 & 1.28 & 1.52 & 10.8 & 1.7 & 62 \\
\hline & & & (1161) & (1411) & & & & & & & & & \\
\hline TK-12 & 18 & 13.62 & 5.47 & 44.25 & 40.88 & 30.64 & 28.8 & 2.5 & 2.15 & 2.56 & & & \\
\hline
\end{tabular}




\begin{tabular}{|c|c|c|c|c|c|c|c|c|c|c|}
\hline \multirow[t]{2}{*}{ TK-13 } & 6 & 13.23 & 4.87 & 54.73 & 54.22 & 13.38 & 25.7 & 3.0 & 1.66 & 1.98 \\
\hline & & & (36) & (405) & & & & & & \\
\hline \multirow[t]{2}{*}{ SWTS-01 } & 50 & 11.12 & 11.18 & 18.57 & 22.10 & 0.00 & 111.1 & 12.6 & 1.65 & 1.96 \\
\hline & & & (1286) & (2135) & & & & & & \\
\hline \multirow[t]{2}{*}{ SWTS-02 } & 22 & 15.16 & 14.96 & 35.47 & 28.10 & 0.00 & 112.1 & 17.9 & 1.70 & 2.02 \\
\hline & & & $(495)$ & (1174) & & & & & & \\
\hline \multirow[t]{2}{*}{ SWTS-04 } & 47 & 14.58 & 20.35 & 24.83 & 21.01 & 5.16 & 205.1 & 9.2 & & 1.81 \\
\hline & & & (1575) & (1922) & & & & & & \\
\hline \multirow[t]{2}{*}{ WY-02 } & 33 & 11.40 & 6.29 & 19.33 & 20.42 & 0.00 & 68.1 & 8.5 & 2.03 & 2.42 \\
\hline & & & $(424)$ & (1303) & & & & & & \\
\hline WY-03 & 50 & 11.28 & 10.71 & 16.68 & 19.1 & 0.00 & 115.7 & 11.9 & 2.01 & 2.39 \\
\hline KK-04 & 50 & 12.04 & 14.22 & 34.83 & 35.85 & 0.00 & 96.2 & 10.8 & 1.56 & 1.86 \\
\hline \multirow[t]{2}{*}{ KK-05 } & 50 & & 5.70 & 11.87 & 13.43 & 0.00 & 109.2 & 11.4 & 2.36 & 2.81 \\
\hline & & & $(442)$ & (921) & & & & & & \\
\hline \multirow[t]{2}{*}{ KK-08 } & 50 & 11.82 & 5.40 & 41.48 & 45.22 & 0.00 & 30.1 & 3.1 & 2.45 & 2.92 \\
\hline & & & (336) & (2580) & & & & & & \\
\hline
\end{tabular}

(No. G is number of individual grains dated per sample; $\rho_{\mathrm{d}}$, the density of induced fission track

density $\left(\right.$ per $\mathrm{cm}^{2}$ ) that would obtained in each individual sample if its $U$ concentration was equal to the U concentration of the CN5 glass dosimeter; $\rho_{\mathrm{s}}$, spontaneous track densities of samples; $\rho_{\mathrm{i}}$, the 
induced track densities of samples; $\mathrm{U}$, the calculated uranium density (in ppm); $\mathrm{P}\left(\chi^{2}\right)$, chi-square probability; Dpar ${ }_{M}$, the measured mean diameter (in $\mu \mathrm{m}$ ) of the etched trace of the intersection of a fission track with the surface of the analyzed apatite crystal, measured parallel to the c axis;

$\operatorname{Dpar}_{C}$, the Dpar ${ }_{M}$ that corrected follow the method in Sobel and Seward, 2010; Age, the apatite fission track age in Ma; error is $\pm 1 \sigma$; length, mean fission track length of the horizontal confined fission tracks in crystal sections. No. L is number of the horizontal confined fission track measured per sample. When $\mathrm{P}\left(\chi^{2}\right)>5 \%$, the age is the pooled age of the sample. When $\mathrm{P}\left(\chi^{2}\right)<$ $5 \%$, the age is the central age. Ages have been calculated using the TRACKKEY software (Dunkl, 2002).)

Table. 3 Apatite fission-track age components

\begin{tabular}{|c|c|c|c|c|}
\hline Samples & No. of Grains & Component 1 & Component 2 & Component 3 \\
\hline \multirow[t]{2}{*}{ KKTM-05 } & 50 & $\pm 9.7 \mathrm{Ma}$ & $145.5 \pm 10.7$ & \\
\hline & & 50.5 & 49.5 & \\
\hline \multirow[t]{2}{*}{ WY-02 } & & $29.9 \pm 3.0$ & $89.6 \pm 3.3$ & $168.7 \pm 3.3$ \\
\hline & & 60.4 & 25.7 & 13.9 \\
\hline \multirow[t]{2}{*}{ KKTM-04 } & 50 & $31.1 \pm 18.8$ & $100.5 \pm 20.5$ & $190.4 \pm 20.5$ \\
\hline & & 38.4 & 28.2 & 33.3 \\
\hline \multirow[t]{2}{*}{ KKTM-08 } & 50 & $15.8 \pm 4.8$ & $105.5 \pm 5.1$ & \\
\hline & & 70.0 & 30.0 & \\
\hline \multirow[t]{2}{*}{ SWTS-02 } & 22 & $28.6 \pm 9.1$ & $83.1 \pm 10.2$ & $184.4 \pm 11.0$ \\
\hline & & 54.1 & 32.2 & 13.7 \\
\hline
\end{tabular}




\begin{tabular}{|c|c|c|c|c|}
\hline \multirow[t]{2}{*}{ SWTS-01 } & 50 & $32.1 \pm 10.8$ & $108.2 \pm 14.6$ & $226.3 \pm 13.7$ \\
\hline & & 39.0 & 25.6 & 35.4 \\
\hline \multirow[t]{2}{*}{ WY-03 } & 50 & $34.5 \pm 5.9$ & $118.6 \pm 7.1$ & $219.9 \pm 7.4$ \\
\hline & & 35.3 & 43.3 & 21.4 \\
\hline
\end{tabular}

The age components were calculated using the Bayesmix software (Jasra et al., 2005; Gallagher, et al., 2009)

Table.4 Zircon U-Pb age groups of the Cenozoic samples

\begin{tabular}{|c|c|c|c|c|c|c|}
\hline sample & No. of & Group1 & Group2 & Group3 & Group4 & Group5 \\
\hline \multirow[t]{2}{*}{ WY-03 } & 79 & $220-331$ & $340-500$ & $626-920$ & $1556-2000$ & $2230-2680$ \\
\hline & & 30.39 & $36.5 \%$ & $8.9 \%$ & $16.5 \%$ & $7.6 \%$ \\
\hline \multirow[t]{2}{*}{ SWTS-01 } & 85 & & $370-505$ & $764-990$ & $1600-2580$ & \\
\hline & & $34.1 \%$ & $35.2 \%$ & $8.2 \%$ & $21.2 \%$ & \\
\hline \multirow{2}{*}{ KKTM-08 } & & $220-310$ & $390-512$ & $600-820$ & $1030-2410$ & \\
\hline & & $11.1 \%$ & $14.8 \%$ & $29.6 \%$ & $37.0 \%$ & \\
\hline \multirow[t]{2}{*}{ KKTM-04 } & 75 & $251-316$ & $353-484$ & $600-1140$ & $1730-2530$ & \\
\hline & & $25.3 \%$ & $34.7 \%$ & $12 \%$ & $25.3 \%$ & \\
\hline \multirow[t]{2}{*}{ WY-02 } & 104 & $240-350$ & $396-543$ & $785-863$ & $1554-1935$ & $2196-2542$ \\
\hline & & $24.0 \%$ & $39.4 \%$ & $7.7 \%$ & $18.3 \%$ & $6.7 \%$ \\
\hline \multirow[t]{2}{*}{ KKTM-05 } & 79 & $243-342$ & $384-486$ & $609-985$ & $1308-1958$ & $2248-2685$ \\
\hline & & $27.8 \%$ & $25.3 \%$ & $16.5 \%$ & $21.5 \%$ & $8.9 \%$ \\
\hline
\end{tabular}

The detrital zircon age group analysis is calculated using Isoplot 3.15. 


\section{Highlight}

1. The deformation of the SW Chinese Tian Shan initiated at 35-25 Ma, and migrated southward at $\sim 15$ Ma.

2. The Atushi and Aksai Basin were separated into two independent basins since the mid-Miocene. 